\title{
Tüketici Hukuku Uyuşmazlıklarında Dava Şartı Arabuluculuk Uygulaması*
}

\author{
Banu Bilge SARIHAN \\ Dr. Öğr. Üyesi, Necmettin Erbakan Üniversitesi, Hukuk Fakültesi, Medeni Hukuk Anabilim Dalı., \\ bbsarihan@yahoo.com, (Sorumlu Yazar / Corresponding Author)
}

\begin{tabular}{|c|c|}
\hline Makale Bilgileri & ÖZ \\
\hline $\begin{array}{l}\text { Anahtar Kelimeler: } \\
\text { Tüketici, Arabuluculuk, } \\
\text { Tüketicinin Korunması } \\
\text { Hakkında Kanun, } \\
\text { tüketici uyuşmazlığı, } \\
\text { dava şartı. }\end{array}$ & 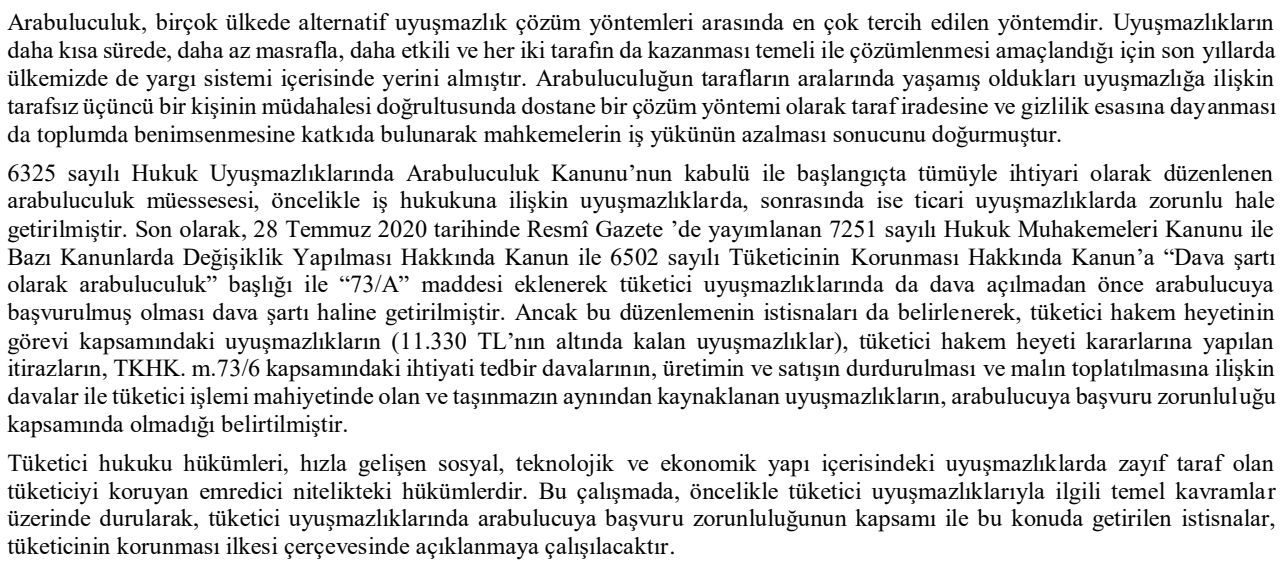 \\
\hline
\end{tabular}

\section{The Practice of Mediation as a Case Condition in a Consumer Law Related to Disputes}

\begin{tabular}{|c|c|}
\hline Article Info & ABSTRACT \\
\hline $\begin{array}{l}\text { Article History } \\
\text { Received: } 21.06 .2021 \\
\text { Accepted: } 11.08 .2021 \\
\text { Published: } 24.08 .2021 \\
\text { Keywords: } \\
\text { Consumer, Mediation } \\
\text { Consumer Protection Law, } \\
\text { Consumer dispute, Case } \\
\text { condition. }\end{array}$ & 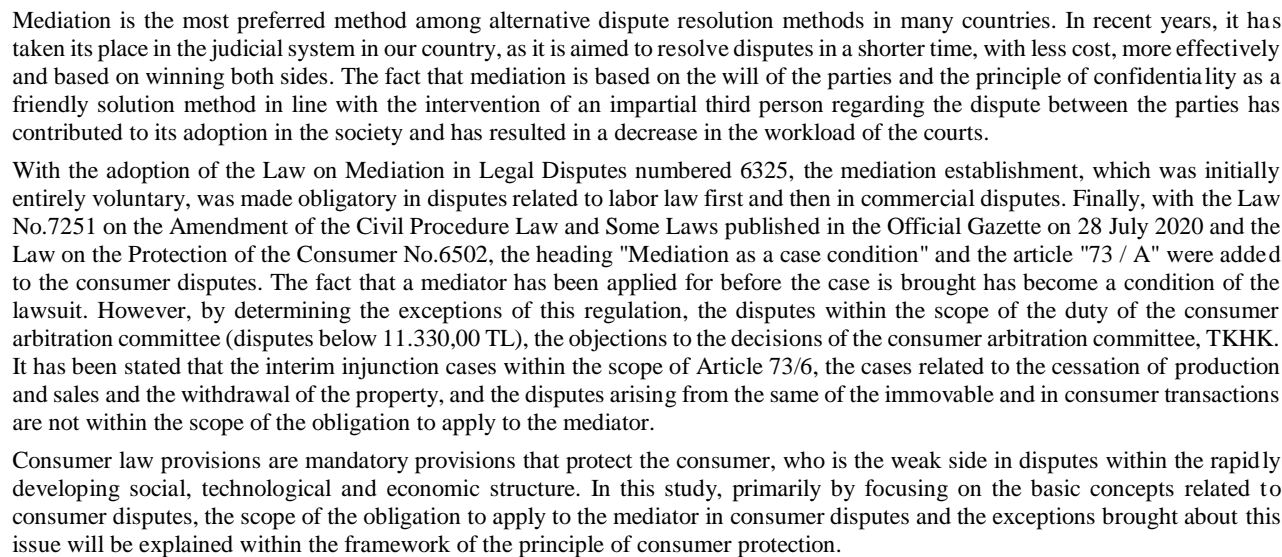 \\
\hline
\end{tabular}

Atıf/Citation: Sarıhan, Banu Bilge. (2021). Tüketici Hukuku Uyuşmazlıklarında Dava Şartı Arabuluculuk Uygulaması, Necmettin Erbakan Üniversitesi Hukuk Fakültesi Dergisi, 4(2), s.415-440.

Plagiarism: Bu makale intihal programında taranmış ve en az iki hakem incelemesinden geçmiştir. // This article has been scanned via a plagiarism software and reviewed by at least two referees.

"This article is licensed under a Creative Commons Attribution-NonCommercial 4.0 International License (CC BY-NC 4.0)"

\footnotetext{
* Bu makale, 10-12 Nisan 2021 tarihinde Necmettin Erbakan Üniversitesi Hukuk Fakültesi tarafindan gerçekleştirilen Uluslararası Necmettin Erbakan Hukuk Kongresi'nde bildiri olarak sunulmuştur.
} 


\section{GİRİŞ}

Toplum halinde yaşamanın kaçınılmaz sonuçlarından biri de ortaya çıkan uyuşmazlıklardır. Uyuşmazlıkların adil bir biçimde çözülebilmesi için alışılagelmiş yöntem olarak devletler yargı yolunu tercih etmiştir. Türkiye Cumhuriyeti Anayasasına göre "Türk Milleti adına yargl yetkisi, bağımsız ve tarafsız mahkemeler tarafindan kullanılır” (AY.m.9). Yine hak arama hürriyetini düzenleyen 36. maddesi uyarınca "Herkes, meşru vasıta ve yollardan faydalanmak suretiyle yargı mercileri önünde davacı veya davalı olarak iddia ve savunma ile adil yargılanma hakkına sahiptir. Hiçbir mahkeme, görev ve yetkisi içindeki davaya bakmaktan kaçınamaz”. Avrupa İnsan Hakları Sözleşmesi’nin “Adil Yargılanma Hakkı”nı düzenleyen 6. maddesine göre de "Herkes davasının, medeni hak ve yükümlülükleriyle ilgili uyuşmazlıklar ya da cezaî alanda kendisine yöneltilen suçlamaların esası konusunda karar verecek olan, yasayla kurulmuş, bağımsız ve tarafsız bir mahkeme tarafindan, kamuya açık olarak ve makul süre içinde görülmesini isteme hakkına sahiptir”. Görüldüğü üzere uyuşmazlık çözümlerinde geleneksel yöntem olarak kabul edilen adli sistem olup, yargı yetkisi mahkemelere aittir. Ancak gerek dünyada gerek ülkemizdeki sosyal, ekonomik, teknolojik vb. gelişmeler neticesinde, uyuşmazlıkların çeşitliliğinin ve yargıdaki iş yükünün artması, yargı sürecinin uzun ve masraflı olması gibi nedenlerle alternatif uyuşmazlık çözüm yöntemlerine ihtiyaç duyulmuştur. Alternatif çözüm yöntemlerinden en aktif tercih edileni arabuluculuk yöntemidir.

Hukuk sistemimizde "Hukuk Uyuşmazlıklarında Arabuluculuk Kanunu” ile öncelikle ihtiyari olarak yer alan arabuluculuk, kanun koyucunun sonradan yaptığı bazı düzenlemelerle belli bazı davalar bakımından zorunlu hale getirilmiştir. Ancak taraflar arabulucuya başvurmak, süreci devam ettirmek, sonuçlandirmak ya da bu süreçten vazgeçmek konusunda serbesttirler (HUAK.m.3/I). Hukukumuzda ilk kez 01.01.2018 tarihinde yürürlüğe giren 7036 sayılı İş Mahkemeleri Kanunu m.3/1 hükmü ile arabuluculuk dava şartı haline gelmiştir. İş uyuşmazlıklarının çözümünde arabuluculuğun başarı sağlaması üzerine, 7155 sayılı Abonelik Sözleşmesinden Kaynaklanan Para Alacaklarına İlişkin Takibin Başlatılması Usulü Hakkındaki Kanun'un 20. maddesiyle, 6102 sayılı Ticaret Kanunu'na 5/A maddesi eklenerek, konusu bir miktar paranın ödenmesi olan alacak ve tazminat talepleri hakkında dava açılmadan önce arabulucuya başvurulmuş olması dava şartı olarak düzenlenmiştir. Dava şartı arabuluculuk ile getirilen son düzenleme çalışma konumuzu da oluşturan tüketici uyuşmazlıklarına ilişkindir. 7251 sayılı Hukuk Muhakemeleri Kanunu ve Bazı Kanunlarda Değişiklik Yapılması Hakkındaki Kanun ile 6502 sayılı Tüketicinin Korunması Hakkında Kanun'a “Dava şartı arabuluculuk” başlığı ile eklenen 73/A maddesi ile tüketici uyuşmazlıklarında da dava açılmadan önce arabulucuya başvurulmuş olması zorunlu hale getirilmiştir.

$\mathrm{Bu}$ çalışmada, öncelikle genel olarak arabuluculuk kavramı özetlenerek, tüketici uyuşmazlıkları açısından getirilen dava şartı arabuluculuk, kapsamı ve istisnaları, uyuşmazlıklarda korunması gereken zayıf tarafı oluşturan tüketicinin korunması temel ilkesi çerçevesinde incelenmiştir. 


\section{GENEL OLARAK ARABULUCUK KAVRAMI}

Uyuşmazlık çözümlerinde adli sistem dışında getirilen, alternatif uyuşmazlık yöntemleri ile daha hızlı, daha ekonomik ve yargı organlarının verdiği kararlardan daha esnek çözümler benimsenmektedir ${ }^{1}$. Alternatif uyuşmazlık çözüm yöntemleri çeşitlilik arz etse de en çok tercih edilenler, müzakere, arabuluculuk, uzlaştırma ve tahkim olarak karşımıza çıkmaktadır. Çalışma konumuzun temelini oluşturan arabuluculuk, alternatif çözüm yöntemleri içerisinde en yaygın kullanılan, hızlı gelişim gösteren bir yöntemdir, terim olarak (mediation) Latince ortayı bulmak ya da yarıya bölmek anlamındaki "mediare" sözcüğünden türemiştir².

Temeli insanlık tarihi kadar eski olan arabuluculuğun farklı tanımları olmakla birlikte yasal olarak 6325 sayılı Hukuk Uyuşmazlıklarında Arabuluculuk Kanunu'nun 2/I-b hükmünde tanımlanmıştır: "arabuluculuk, sistematik teknikler uygulayarak, görüşmek ve müzakerelerde bulunmak amacıyla tarafları bir araya getiren, onların birbirlerini anlamalarını ve bu suretle çözümlerini kendilerinin üretmesini sağlamak için aralarında iletişim sürecinin kurulmasını gerçekleştiren, tarafların çözüm üretemediklerinin ortaya çıkması halinde çözüm önerisi de getirebilen, uzmanlık eğitimi almış olan tarafsız ve bağımsız bir üçüncü kişinin katılımıyla ve ihtiyari olarak yürütülen uyuşmazlık çözüm yöntemidir."’. Tanımda da ifade edildiği gibi arabuluculuğun temeli, tarafsız üçüncü bir kişinin, taraflar arasındaki iletişimi sağlayarak, onların menfaat temelli kendi çözümlerini bulabilmelerine imkân sağlaması ve bu şekilde uyuşmazlığın gönüllülük esasına dayalı çözüme kavuşturulmasıdır ${ }^{4}$. Arabulucu, hâkim ya da hakem statüsünde

1 Moore, Cristopher W. Arabuluculuk Süreci, Anlaşmazllk Çözümünde Pratik Stratejiler, The Mediation Process, (Çev. Tarkan Kaçmaz, Mustafa Tercan), 4. B., Ankara, 2016, s.2 vd.; Özbek, Mustafa. Alternatif Uyuşmazlık Çözümü, C. 1, 4. B., Ankara, 2016, s. 191; Tanrıver, Süha. "Alternatif Uyuşmazlık Çözüm Yolları: Arabuluculuk Kurumuna Hukukî ve Sosyolojik Bir Bakış", Prof. Dr. Fikret Eren'e Armağan, Ankara, 2006, s. 821-842; Tanrıver, Süha. Hukuk Uyuşmazlıkları Bağlamında Alternatif Uyuşmazlık Çözüm Yolları ve Özellikle Arabuluculuk, Makalelerim II, Ankara, 2011, s.4 vd.; Sarısözen, Serhat. "Hukuk Uyuşmazlıklarında Arabuluculuk Kanun Tasarısının Getirdikleri, İcra Edilebilirlik Belgesi ve Arabuluculuğun Avukatın Tekel Hakkına Aykırılık Oluşturup Oluşturmadığı Sorunu", EÜHFD., C.XV, 2011/1-2, s.256; Çelikoğlu, Cengiz Topel. "6325 Sayılı HUAK'a göre Arabuluculuk Yoluna Başvurulması ve Çözüm Anlaşmasının Mahkeme ve İcra Usulleri ile İlişkisi”, Prof. Dr. Ejder Yllmaz' a Armağan, C.I, Ankara, 2014, s.678; Pekcanıtez, Hakan/ Özekes, Muhammet/ Akkan, Mine/Korkmaz Taş, Hülya. Medenî Usul Hukuku, 15. Bask1, C. 3, İstanbul, 2017, s. 2807; Arslan, Ramazan/ Yılmaz, Ejder/Taşpınar Ayvaz, Sema/Hanağası, Emel. Medenî Usul Hukuku, 5. Baskı, Ankara, 2019, s. 778; Ildır, Gülgün. "Alternatif Uyuşmazlık Çözümü ve Hak Arama Özgürlügüu”, 75. Yaş Günü için Prof. Dr. Baki Kuru Armağanı, Ankara, 2005, s. 385.

2 Özmumcu, Seda. Uzak Doğu'da Arabuluculuk Anlaylşı ile Türk Hukuk Sisteminde Arabuluculuk Kurumuna Genel Bir Bakış, 3. Baskı, İstanbul ,2013, s. 276; Ildır, Gülgün. Alternatif Uyuşmazlık Çözümü, Ankara, 2003, s. 78; Tıktık Yazıcı, Çiğdem. Arabuluculukta Gizliliğin Korunması, İstanbul, 2013, s. 6; Tuğsavul Taşpolat, Melis. Türk Hukukunda Arabuluculuk, Ankara, 2012, s. 21.

36325 sayll HUAK.m.2/I-b bendine 12.10.2017 tarihli ve 7036 sayll Kanunun 17. maddesi ile eklenen, "gerçekleştiren," ibaresinden sonra gelmek üzere "tarafların çözüm üretemediklerinin ortaya çıkması halinde çözüm önerisi de getirebilen," ifadesi ile HUAK.m.15'e, 12.10.2017 tarihli ve 7036 sayılı Kanunun 22. maddesinin 7.fikrası ile eklenen "tarafların çözüm üretemediklerinin ortaya çıkması halinde arabulucu bir çözüm önerisinde bulunabilir" ifadesi, çözüm önerisi sunma yetkisi olmayan arabulucuya, süreç, içerisinde çözüm üretme noktasında tıkanıklık yaşayan taraflara çözüm önerisinde bulunabilme imkanını vermiş, böylelikle arabulucunun faaliyet alanı aktifleştirilmiştir.

4 Tuğsavul Taşpolat, 2012, s. 26, Ildır, 2003, s.21; Tıktık Yazıcı, s. 5; Kekeç, Elif Kısmet. Arabuluculuk Yoluyla Uyuşmazlık Çözümünde Temel Aşamalar ve Taktikler, 3. Baskı, Ankara, 2016, s. 11; Sevim, Onur Utku. Avrupa 
olmadığı için uyuşmazlık hakkında karar verme yetkisine sahip değildir, tarafların uyuşmazlık konusunda kendi kararlarını vermesini sağlayarak dava yoluna gitmeden çözüme ulaşmayı amaçlar ${ }^{5}$. Arabuluculuk, mahkemeler yerine geçen bir sistem olmayıp, yargısal yolların yanında yer alan alternatif nitelikteki bir çözüm yöntemidir, sadece iç hukuklarda değil, uluslararası ilişkilerin düzenlenmesi noktasında da aktif olarak kullanılmaktadır ${ }^{6}$.

\section{A. Arabuluculuk Yönteminin Tercih Sebepleri}

Alternatif uyuşmazlık çözüm yöntemleri içerisinde en çok tercih edilen yöntem arabuluculuktur ${ }^{7}$. Arabuluculuk yönteminin diğer yöntemlere nazaran tercih edilmesinin sebebi arabuluculuk sisteminin özelliklerinden kaynaklanmaktadır.

Hukuk Uyuşmazlıklarında Arabuluculuk Kanunu'nda da belirtildiği üzere arabuluculuğun en önemli özelliği gönüllülük esasına dayanmasıdır; "Taraflar, arabulucuya başvurmak, süreci devam ettirmek, sonuçlandırmak veya bu süreçten vazgeçmek konusunda tamamen serbesttirler", (HUAK.m.3) ${ }^{8}$. Yargısal yöntemde karar verme yetkisi hakimlerde olmasına karşılık, arabuluculukta tüm yetki ve irade taraflardadır. Taraflar serbest ve açık bir müzakere süreci içerisinde dış baskıya maruz kalmadan görüşmeler yapabilir, bu sürecin olumlu sonuçlanmaması ihtimalinde yine yargıya başvurabilirler ${ }^{9}$. Arabuluculuğun bir diğer özelliği, menfaat temelli bir yöntem olmasıdır. Yargısal uyuşmazlık çözümünde haklılık ve adalet esasken, arabuluculukta taraflar uyuşmazlığı daha esnek olarak kendi istek ve ihtiyaçlarını ön plana alarak çözüme kavuşturabilirler ${ }^{10}$. Uyuşmazlığın çözüm sürecinde, taraflar aralarındaki uyuşmazlık konusu hakkında uzman, tarafsız ve bağımsız üçüncü kişiyi (arabulucuyu) kendileri seçerler. Arabulucu

Birliği Müktesebatı ve Türk Hukukunda Arabuluculuk, Ankara, 2016, s. 7; Bulur, Alper. "Alternatif Uyuşmazlık Çözüm Yolları ve Arabuluculuk Yöntemi”, ABD, S. 4, 2007, s. 31; Dür, Orhan. Arabuluculuk Faaliyeti ve Arabulucuların Hak ve Yükümlülükleri, 2. Bask1, Ankara, 2018, s. 5; Özbay, İbrahim. “Alternatif Uyuşmazlık Çözüm Yöntemleri”, EÜHFD., C. X, S. 3-4, 2006, s. 459; İlhan, Onur. Arabuluculuk Sözleşmesi, Ankara, 2020, s.42; Abugalı, Gulden. Tüketici Hukukundan kaynaklanan Uyuşmazlıkların Türk ve Rus Hukukuna Göre Arabuluculukla Çözülmesi, Ankara, 2020, s.43.

5 Roberts, Marien. Aile Uyuşmazlıklarında Arabuluculuk Uygulama Esasları, Ankara, 4.Basımdan Çeviri, Şubat, 2020, s.9; Taşpolat Tuğsavul, 2012, s.26; Tanrıver, 2006, s.827, Bercovitch, Jacob. International Mediation, Chicago, 1991, syf.3 ; Güngör, Hüseyin. Arabuluculuk, Ankara, 2008, s.44, Sabuncuoğlu, Zeyyad Ziya. Hukuk Uyuşmazlıklarında Arabuluculuk, Bursa, 2016, s.21.

6 Tanriver, 2011, s.151.

7 Kekeç, s.23; Özbek, s. 592; İlhan, s.30.

8 Ek cümle: (6/12/20187155/22 md.) “Şu kadar ki dava şartı arabuluculuğa ilişkin 18/A maddesi hükmü saklıdır. ”. İhtiyari arabuluculuk yönteminde tamamen tarafların iradesine bağlı şekilde bir başvuru serbestisi olmasına karş1lık zorunlu arabuluculuk yönteminde arabulucuya başvuruyu zorunlu kılan bir kanunî düzenleme mevcuttur. Arabuluculuğa başvurmanın kanun tarafindan zorunlu tutulmuş olması, gönüllülük esasına bir engel teşkil etmez, zira zorunlu arabuluculukta da sürecin devam ettirilmesi, tarafların bir anlaşmaya varması iradîdir ve uyuşmazlığ 1 arabuluculuk faaliyetiyle değil de yargılama faaliyetiyle çözümlemek isteyen kişi, arabuluculuk sürecini sonlandırarak mahkemede dava açabilecektir. AYM., 10.7.2013, E. 2012/94 K. 2013/89 “...Alternatif uyuşmazlık çözümü kavramında geçen “alternatif” terimi, mahkemelere alternatif bir yol olarak kullanılamaz. Arabuluculuk, tarafların sorunlarını kendilerinin çözmesini amaçlayan gönüllülük esasına dayanan dostane bir çözüm yolu olup bir yargılama faaliyeti değildir...” RG. 25.01.2014, S. 28893.

9 Albayrak, Âdem /Koçyiğit İlker. Sorularla Arabuluculuk Sınavına Hazırlık, Adalet Yayınevi, Ankara, 2019, s.41, Ekmekçi, Ömer/Özekes, Muhammet/Atalı, Murat. Hukuk Uyuşmazlıklarında İhtiyarî ve Zorunlu Arabuluculuk, İstanbul, 2018, s. 25; Dür, Orhan. Arabuluculuk Faaliyeti ve Arabulucuların Hak ve Yükümlülükleri, 2. Bask1, Ankara, 2018, s. 249.

10 Tuğsavul Taşpolat , 2012, s. 29; Albayrak/Koçyiğit, s.41; İlhan, 53; Kekeç, s.95. 
uyuşmazlık konusunu inceleyip değerlendirerek taraflara teknik ve detaylı destek sağlar ${ }^{11}$. Taraflar yargısal yöntemde aralarındaki uyuşmazlığı çözüme kavuşturacak hâkimi seçemezken, arabuluculukta arabuluculuk sicilinde kayıtlı olan kişiler arasından seçim yapabilirler ${ }^{12}$. Taraflar çözüm için anlaşmaya varamazlarsa süreci sonlandırabilirler. Ancak arabulucunun desteği ile sürecin olumlu ilerlemesi sonucunda taraflar anlaşırlarsa bu anlaşma taraf iradelerine dayandığı, geçmiş değil geleceğe odaklanıldığı ve her iki tarafın da menfaati tatmin edildiği için uyuşmazlığın bir kaybedeni olmayacaktır (kazan/kazan kuralı), yargısal çözümde ise, mahkemenin mevzuatı esas alarak haklılık kriterine göre verdiği hüküm neticesinde taraflardan biri davayı kazanırken diğer taraf kaybedecektir (kazan/kaybet kuralı) ${ }^{13}$. Ayrıca arabuluculuk faaliyeti, taraflar arasında husumet oluşmasına engel olarak, tarafların gelecekteki sosyal ve ticari ilişkilerini de koruyacaktır ${ }^{14}$.

$\mathrm{Bu}$ yöntemin diğer bir özelliği de sürecin tamamen gizlilik esasına dayanıyor olmasıdır. Kanundan kaynaklanan istisnalar haricinde veya taraflarca aksi kararlaştırılmadığ sürece $^{15}$, arabuluculuk görüşmeleri gizlidir (HUAK.m.4). Hem taraflar hem de arabulucu bu kurala riayetle yükümlüdür. Arabuluculuk sürecinde gerek olağan oturumlarda gerekse özel oturumlarda edinilen bilgi ve belgeler ne diğer tarafla ne de üçüncü kişilerle paylaşılamaz ${ }^{16}$. Yine arabuluculuk faaliyetinin olumlu sonuçlanmaması halinde, elde edilen bilgi ve belgelerin de yargılama sürecinde delil olarak da kullanılamayacağı hükme bağlanmıştır (HUAK.m.5) ${ }^{17}$. Arabuluculuk yönteminin

11 Kekeç, s.90; Özbek, s. 288; İlhan, s.49, Albayrak/Koçyiğit, s.43.

12 HUAK (Hukuk Uyuşmazlıklarında Arabuluculuk Kanunu) 20. maddesinde arabulucular siciline kayıt şartları belirtilmiştir. Buna göre; (2) Arabulucular siciline kaydedilebilmek için;

a) Türk vatandaşı olmak,

b) Mesleğinde en az beş yıllık kıdeme sahip hukuk fakültesi mezunu olmak,

c) Tam ehliyetli olmak,

ç) (Değişik: 12/10/2017-7036/25 md.) 26/9/2004 tarihli ve 5237 sayılı Türk Ceza Kanununun 53 üncü maddesinde belirtilen süreler geçmiş olsa bile; kasten işlenen bir suçtan dolayı bir yıldan fazla süreyle hapis cezasına ya da affa uğramış olsa bile Devletin güvenliğine karşı suçlar, Anayasal düzene ve bu düzenin işleyişine karşı suçlar, zimmet, irtikâp, rüşvet, hırsızlık, dolandırıcılık, sahtecilik, güveni kötüye kullanma, hileli iflas, ihaleye fesat karıştırma, edimin ifasına fesat karıştırma, suçtan kaynaklanan malvarlığı değerlerini aklama veya kaçakçılık, gerçeğe aykırı bilirkişilik yapma, yalan tanıklık ve yalan yere yemin suçlarından mahkûm olmamak,

d) (Ek: 5/6/2017-KHK-691/9 md.; Aynen kabul: 31/1/2018-7069/9 md.) Terör örgütleriyle iltisaklı veya irtibatlı olmamak,

e) Arabuluculuk eğitimini tamamlamak ve Bakanlıkça yapılan yazılı (...) sınavda başarılı olmak, gerekir.

13 Özbek, s.300; Yazıcı T1ktık, s.47; Tanrıver, s.158; İlhan, s.55.

14 Kekeç, s.90; Özbek, s.304; İlhan, s.62.

15 Arabuluculukta gizlilik ilkesi bazı hâllerde devre dışı kalabilir. Tarafların, kendi sundukları bilgi ve belgelerin açıklanmasına, paylaşılmasına rıza göstermeleri halinde, yine aralarında yapacakları arabulucuya başvurma sözleşmesinde ya da arabulucu ve taraflar arasında yapılacak olan arabuluculuk sözleşmesinde, gizlilik ilkesinin aksini kararlaştırmaları halinde, ayrıca kanundan kaynaklanan istisnai hallerde de gizlilik ilkesi uygulanmayacaktır. HUAK.m.5/III gereğince, söz konusu beyan ve belgelerin, bir kanun hükmü tarafından emredildiğinde yahut arabuluculuk süreci sonunda varılan çözüm anlaşmasının uygulanması ve icrası için gerekli olduğu ölçüde açıklanabileceği ifade edilmiştir.

16 Yazıcı Tıktık, s.54; Kekeç, s.79; İlhan, s.58; Özbek, s.292; Hukuk Uyuşmazlıklarında Arabuluculuk Kanunu 33. maddesi ile, gizlilik ilkesini ihlal ederek bir kişinin hukuken korunan menfaatinin zarar görmesine neden olan kişinin şikâyet üzerine altı aya kadar hapis cezası ile cezalandırılacağı hükme bağlanmıştır.

17 HUAK. m.5 /I : "Taraflar, arabulucu veya arabuluculuğa katılanlar da dahil üçüncü bir kişi, uyuşmazlıkla ilgili olarak hukuk davası açıldığında veya tahkim yoluna başvurulduğunda aşağıdaki beyan ve belgeleri delil olarak ileri süremez ve bunlar hakkında tanıklık yapamaz:

a) Taraflarca yapılan arabuluculuk daveti veya bir tarafın arabuluculuk faaliyetine katılma isteği. 
gizliliği, taraflar arasındaki güven duygusunu artırarak daha verimli iletişimin sağlanabilmesine, arabulucunun da süreci daha iyi idare ederek tarafların kendi çözümlerine ulaşmalarına ve neticede yöntemin başarısına yardımcı olur ${ }^{18}$. Devlet mahkemelerindeki yargısal çözüm sürecinde ise, genel ahlâk veya kamu güvenliğinin gerektirdiği hâller dışında aleniyet esastır, duruşmalar herkese açık yapılır. Aleniyet ilkesi nedeniyle herkese açık olan yargılama sürecinde, tarafların özel ya da ticari hayatlarıyla ilgili bazı ayrıntıların ve sırların ifşa olması endişesi arabuluculuğun önemli tercih sebeplerinden birini oluşturmaktadır ${ }^{19}$. Toplum hayatında sosyal, ekonomik, teknolojik anlamdaki hızlı değişim, uyuşmazlıkların da artmasına neden olmuştur. Artan uyuşmazlıklar mahkemelerin iş yükünü yoğunlaştırmış, yargılama sürelerinin uzamasına, masrafların da artmasına neden olmuştur. Arabuluculuk yönteminde ise uyuşmazlık çözümü mahkemelere nazaran hem daha az masraflı hem de daha hızlı bir şekilde (birkaç saat içinde dahi) çözüme kavuşturulabiliir ${ }^{20}$. Görüldüğü üzere arabuluculuğun özellikleri yargısal ç̧̈züm yöntemlerine alternatif olarak uygulamada giderek daha fazla tercih edilmesi sonucunu doğurmuştur.

\section{B. Dava Şartı Olarak Arabuluculuk}

Arabuluculuk alternatif bir uyuşmazlık çözüm yöntemi olarak gönüllülük (iradilik) esasına dayandığı için yapısına uygun olan arabuluculuğun ihtiyari olmasıdır. Nitekim, Hukuk Uyuşmazlıklarında Arabuluculuk Kanununa göre kural olarak arabuluculuk ihtiyaridir. Taraflar arabulucuya başvurmak, süreci devam ettirmek, sonuçlandırmak ya da bu süreçten vazgeçmek konusunda serbesttirler (HUAK.m.3/I). Ancak kanun koyucunun sonradan yaptığı bazı düzenlemelerle belli bazı davalar bakımından arabulucuya başvuru zorunlu hale getirilmiştir. Zorunlu arabuluculuk olarak da ifade edilen bu yöntemde, arabulucuya başvuru zorunluluğu, sadece arabuluculuk sürecinin başlatılmasına ilişkindir. Taraflar, süreci devam ettirip ettirmeme, süreç sonucunda anlaşmaya varıp varmamak konusunda serbest olup, anlaşmaya varılamaması halinde uyuşmazlı̆ı̆ı çözümü için yargı yoluna da başvurabilirler ${ }^{21}$.

Hukukumuzda ilk kez 01.01.2018 tarihinde yürürlüğe giren 7036 sayılı İş Mahkemeleri Kanunu md.3/1 hükmü ile arabuluculuk dava şartı haline gelmiştir. Bir başka deyişle, arabulucuya başvurulmadan dava açılması halinde mahkeme davayı dava şartı eksikliği nedeniyle usulden reddedecektir ${ }^{22}$. Kanun hükmüne göre; "Kanuna, bireysel veya toplu iş sözleşmesine dayanan işçi

b) Uyuşmazlığın arabuluculuk yolu ile sona erdirilmesi için taraflarca ileri sürülen görüşler ve teklifler.

c) Arabuluculuk faaliyeti esnasında, taraflarca ileri sürülen öneriler veya herhangi bir vakıa veya iddianın kabulü.

ç) Sadece arabuluculuk faaliyeti dolayısıyla hazırlanan belgeler".

Arabuluculukta sunulan her belgenin yahut verilen her bilginin, daha sonra yapılacak bir yargilamada delil olarak kullanılamayacağ 1 mutlak değildir. HUAK.m.5/V'te, bir belgenin, sirf arabuluculuk faaliyetinde sunulmas nedeniyle kabul edilemeyecek delil haline gelmeyeceği özellikle belirtilmiştir.

18 Yazıcı Tıktık, s.51; Günay, s.84; Kekeç, s.83-84; İlhan, s.57.

19 Özbek, s.292; Şahin, Tuğçem/Çelik, Yasin/Ruhi, Ahmet Cemal. Hukuk Uyuşmazlıklarında Arabuluculuk Rehberi, Ankara, 2018, s. 48.

20 Özbek, Mustafa. "Avrupa Konseyi Arabuluculuk Yönergesi Önerisi”, AÜHFD., C. 56, S. 1, 2007, s. 183-231; Kekeç, s.88; İlhan, s.61.

21 Kekeç, s.71; Özbek, s.308; Yazıcı Tıktık, s.40.

22 Mahkemenin davanın esası hakkında yargılama yapabilmesi için varlığı veya yokluğu gerekli olan şartlara dava şartları denir. Dava şartları davanın açılabilmesi için değil, mahkemenin davanın esası hakkında inceleme yapabilmesi için gereken şartlardır, dava şartlarının varlığı veya yokluğu mahkemece re 'sen gözetilir, gerekli dava şartlarının yokluğu halinde, hâkim davayı usulden reddeder. Genel dava şartları HMK'nun 114. Maddesinde 
veya işveren alacă̆ $\mathrm{l}$ ve tazminatı ile işe iade talebiyle açılan davalarda, arabulucuya başvurulmuş olması dava şartıdır”. İş uyuşmazlıklarının çözümünde arabuluculuğun başarı sağlaması üzerine, 7155 sayılı Abonelik Sözleşmesinden Kaynaklanan Para Alacaklarına İlişkin Takibin Başlatılması Usulü Hakkındaki Kanun'un 20. maddesiyle, 6102 sayılı Ticaret Kanunu'na 5/A maddesi eklenmiştir. Buna göre, “Bu Kanunun 4'üncü maddesinde ve diğer kanunlarda belirtilen ticari davalardan, konusu bir miktar paranin ödenmesi olan alacak ve tazminat talepleri hakkinda dava açılmadan önce arabulucuya başvurulmuş olması dava şartıdır” (TTK.m.5/A). Bu düzenlemenin 01.01.2019 tarihinde yürürlüğe girmesiyle beraber, ticarî davalarda, konusu para olan alacak ve tazminat talepleri için de öncelikle arabulucuya başvurulmuş olması gerekmektedir.

Dava şartı arabuluculuk ile getirilen son düzenleme çalışma konumuzu da oluşturan tüketici uyuşmazlıklarına ilişkindir. 7251 sayılı Hukuk Muhakemeleri Kanunu ve Bazı Kanunlarda Değişiklik Yapılması Hakkındaki Kanun ile 6502 sayılı Tüketicinin Korunması Hakkında Kanun'a "Dava şartı arabuluculuk" başlı̆̆ı ile eklenen 73/A maddesi ile tüketici uyuşmazlıklarında da dava açılmadan önce arabulucuya başvurulmuş olması zorunlu hale getirilmiştir. Düzenlemede, arabuluculuğa başvuru zorunluluğu kapsamındaki uyuşmazlıklar ve istisnaları ile arabuluculuk ücretinin ödenme usulüne yer verilmiştir. Madde kapsamındaki haller dışında tüketici uyuşmazlıklarında arabuluculuğa başvuru zorunluluğu HUAK.md 18/A hükmüne tabidir $^{23}$.

\section{TÜKETİCI HUKUKUNDA ARABULUCULUK}

\section{A. Tüketici Uyuşmazlıklarının Arabuluculuğa Elverişliliği}

19.yüzyıl sanayi devrimi ile seri üretime geçilmesi sonucu üretimin artması tüketim faaliyetlerinin de artması sonucunu doğurmuştur. Tüketim faaliyetleri öncelikle temel ihtiyaçların giderilmesi için yapılsa da çağımızda bilgi ve iletişim teknolojilerinin hızla gelişmesi ile tüketim artık amaç haline gelmiş, kitlesel üretimler kitlesel tüketimlere neden olmuştur ${ }^{24}$. Ancak tüketicinin her ihtiyaç duyduğu mal ve hizmet için yeterli bilgi sahibi olması mümkün değildir. Tüketiciler mal ve hizmet sunucuları karşısında gerek bilgi, tecrübe ve entelektüel eksiklikler gerekse ekonomik sebeplerle güçsüz konumdadırlar. $\mathrm{Bu}$ durum tüketici ilişkisinde satıc1/sağlayıcı/girişimci tarafı üstün taraf haline getirirken tüketici zayıf tarafı teşkil etmektedir ${ }^{25}$.

düzenlenmiş ve diğer kanunlarda yer alan dava şartlarına ilişkin hükümler saklı tutulmuştur. Ayrıntılı bilgi için bkz: Kuru, Baki/ Arslan, Ramazan/ Yılmaz, Ejder. Medenî Usul Hukuku, 25. Baskı, Ankara, 2014, s.244; Pekcanıtez, Özekes, Akkan, Korkmaz Taş, 2017, s.925; Atalı, Murat/ Ermenek, İbrahim/ Erdoğan, Ersin. Medenî Usul Hukuku, 2. Bask1, Ankara, 2019, s.317.

23 Arabuluculuğa başvuru zorunluluğuna ilişkin genel usul hükümleri, 06.12.2018 tarihi 7155 sayılı Kanun'un 23. maddesiyle 6325 sayılı Kanun'a eklenen 18/A maddesinde düzenlenmiştir. Dava şartı olarak arabuluculuğun söz konusu olduğu hâllerde (İMK.md.3; TTK.m.5/A; TKHK.m.73/A) öncelikle ilgili özel düzenleme uygulanacak, belirtilen özel haller dışında Kanun'un 18/A maddesine dikkate alınacaktır. Dava şartı olarak arabuluculuğa başvurulmadan açılan davalar usulden reddedilir. Arabulucuya başvurulup anlaşmaya varılamadığı hallerde ise buna ilişkin son tutanağın aslını ya da arabulucu tarafından onaylanmış bir örneğinin dava dilekçesine eklenmesi zorunludur, aksi hâlde mahkeme, davacıya, son tutanağı sunması için bir haftalık kesin süre verir, kesin süre içinde tutanak davacı tarafından sunulmazsa dava dilekçesi karşı tarafa tebliğ edilmeksizin usulden reddedilir (HUAK.m.18/A-2).

24 Aslan, İ.Y1lmaz. Tüketici Hukuku Dersleri, 8.Bask1, Ankara, 2021, s.1 vd.,

25 Özel, Çağlar. Tüketicinin Korunması Hukuku, Ankara, 2019, s.43, Güngör Güneysu, Gülin. Milletlerarası Özel Hukukta Tüketicinin Korunmast, Ankara, 2000, s.22. 
Tüketicilerin üreticiler kadar kolay örgütlemeyecekleri, ekonomik ve politik anlamda bir bask1 grubu olarak etkin olamayacakları da açıktır. Bu nedenle birçok ülke mevzuatlarında tüketicileri koruyucu hükümlere yer verilmiştir ${ }^{26}$. Bizim hukuk sistemimizde de zayıf olan tüketicinin devlet eliyle korunmasına yönelik emredici nitelikteki hükümler içeren düzenlemeler mevcuttur. Anayasamızın 172. maddesi uyarınca "Devlet, tüketicileri koruyucu ve aydınlatıcı tedbirleri alma ve tüketicilerin kendilerini koruyucu girişimlerini teşvik etmekle” yükümlüdür. Bu hükmün gereği olarak, önce 4077 sayılı Tüketicinin Korunması Hakkında Kanun çıkarılmış, akabinde birçok ihtiyacı karşılayamaması nedeniyle, bu kanun yürürlükten kaldırılarak, 2014 yılında evrensel tüketici hakları doğrultusunda hazırlanan 6502 sayılı Tüketicinin Korunması Hakkında Kanun yürürlüğe girmiştir. Kanunun amacı, kamu yararına uygun olarak tüketicinin sağlık ve güvenliği ile ekonomik çıkarlarını koruyucu, zararlarını tazmin edici, çevresel tehlikelerden korunmasını sağlayıcı, tüketiciyi aydınlatıcı ve bilinçlendirici önlemleri almak, tüketicilerin kendilerini koruyucu girişimlerini özendirmek ve bu konudakisi politikaların oluşturulmasında gönüllü örgütlenmeleri teşvik etmek olarak ifade edilmiştir (6502 sayılı Kanun; m.1). Mevzuat içerisinde yer alan zayıf konumdaki tüketiciyi korumak amaçlı düzenlemelerin kamu düzenine ilişkin olması, tüketici uyuşmazlıklarında tarafların tasarruf yetkisini ortadan kaldırmaz. Arabuluculuğa elverişlilikte aranan ölçüt de uyuşmazlık konusunda tarafların serbestçe tasarruf edebilmeleridir ${ }^{27}$. Taraflar aralarındaki uyuşmazlık ile ilgili olarak mahkemeye gitmeksizin kendi serbest iradeleri ile hareket edip hukuken korunan bir sonuç elde edebiliyorlarsa, o konu arabuluculuğa elverişli olarak kabul edilmektedir ${ }^{28}$.

Tüketici uyuşmazlıkları, Tüketicinin Korunması Hakkında Kanun'un 68/5 ve 73/A hükümleri çerçevesinde arabuluculuğa elverişlidir. TKHK.m.68/5 hükmünde "Bu madde tüketicilerin ilgili mevzuatına göre alternatif uyuşmazlık çözüm mercilerine başvurmasına engel değildir" şeklinde ifade edilen düzenlemede, Tüketici Hakem Heyetlerine başvuru yapılmasının alternatif uyuşmazlık yollarına başvuru yapılmasına engel teşkil etmeyeceği düzenlenmiştir. Yine dava şartı arabuluculuğu düzenleyen 73/A hükmünden de anlaşılacağı üzere tüketici mahkemelerinin görev alanında kalıp, tarafların üzerinde serbestçe tasarruf edebilecekleri her türlü uyuşmazlık arabuluculuğa elverişlidir ${ }^{29}$. Madde hükmünde, arabuluculuğa elverişlilik bakımından uyuşmazlığın tüketici mahkemelerinin görev alanına girmesi kriter olarak kabul edildiğinden,

26 Uyumaz, Alper. "Tüketici Hukukundan Doğan Alternatif Çözüm Yolları”, SÜHFD., C.20, S.1,2012, s.118.

27 Koçyiğit,İlker/Yeşilkaya,İzzet. Ticari Davalarda, İş Uyuşmazlıklarında, Tüketici Mahkemelerinde Dava Şartı Arabuluculuk Uygulamaları, Ankara, 2020, s.191. Arabuluculuğa elverişliliğin genel çerçevesi HUAK.m.1/2 uyarınca tespit edilmiştir; "Bu Kanun yabancılık unsuru taşıyanlar da dahil olmak üzere, ancak tarafların üzerinde serbestçe tasarruf edebilecekleri iş ve işlemlerden doğan özel hukuk uyuşmazlıklarının çözümünde uygulanır. Şu kadar ki, aile içi şiddet iddiasını içeren uyuşmazlıklar arabuluculuğa elverişli değildir”. Kanun hükmünden de anlaşıldığı üzere, kamu hukuku uyuşmazlıkları arabuluculuğa elverişli değildir, yine özel hukuka ilişkin olup da tarafların üzerinde serbestçe tasarruf edemedikleri iş ve işlemler de arabuluculuğa elverişli değildir. Mesela, kamu düzenini yakından ilgilendiren ve uyuşmazlığın çözümü için mutlaka mahkeme kararına ihtiyaç duyulan boşanma davalarında arabuluculuğa gidilemez.

28 Ermenek, İbrahim. "Dava Şartının Arabulucu Tarafından Kendiliğinden Dikkate Alınması Sorunu ve Bu Kapsamda Yapılan Hataların Düzeltilmesi”, YD.2020/4, C.46, s.1042-1043., Akipek, Şebnem/Yıldırım, Abdülkerim/Ermenek, İbrahim/Kutlay, Selda. Tüketici Hukukunda Uzman Arabuluculuk, AB.Hukuk İsleri Genel Müdürlüğ̈̈ Arabuluculuk Daire Başkanlı̆̆g Temel Eğitim Kitapçı̆̆g, Ankara, 2021, s.124-126.

29 Tüketici hakem heyetlerinin görev alanına giren uyuşmazlıklar için dava şartı olmasa da ihtiyari olarak arabuluculuğa gidebilir. 
uyuşmazlığın maddi hukuk bakımdan dayanağı, davanın usulî niteliği, cebri icra hukuku alanına ilişkin olup olmadığı dikkate alınmaz ${ }^{30}$.

\section{B. Tüketici Uyuşmazlıklarında Arabuluculuğa Başvuru Zorunluluğunun Kapsamı ve İstisnaları}

1. Kapsam

Dava şartı arabuluculuk müessesesi, 28/07/2020 tarih ve 31199 say1lı Resmî Gazete 'de yayımlanarak yürürlüğe giren 7251 sayılı Hukuk Muhakemeleri Kanunu ile Bazı Kanunlarda Değişiklik Yapılması Hakkındaki Kanun ile 6502 sayılı Tüketicinin Korunması Hakkında Kanun'a eklenen 73/A maddesi ile tüketici uyuşmazlıklarında zorunlu hale getirilmiştir.

$\mathrm{Bu}$ düzenleme ile tüketici mahkemelerinde ya da tüketici mahkemesi oluşturulmayan yerlerde tüketici mahkemesi sifatıyla hareket eden asliye hukuk mahkemelerinde görülen uyuşmazlıklarda dava açılmadan önce arabulucuya başvurulması dava şartı olarak kabul edilmiş, ancak kanun hükmünde belirtilen hususlar istisna olarak kabul edilmiştir, dava şartı arabuluculuk kapsamı dişında tutulmuştur. Yine Hukuk Uyuşmazlıkları Arabuluculuk Kanunundaki ilgili hükümlerin tüketicinin korunması esasından hareketle tüketiciler aleyhine uygulanamayacağı da özellikle belirtilmiştir.

"Dava şartı arabuluculuk başlı̆̆ını taşlyan, TKHK. md. 73/A- Ek: 22.07.2020-7251/59 hükmü şu şekilde düzenlenmiştir:

(1) Tüketici mahkemelerinde görülen uyuşmazlıklarda dava açılmadan önce arabulucuya başvurulmuş olması dava şartıdır. Şu kadar ki, aşă̆ıda belirtilen hususlarda dava şartı olarak arabuluculuğa ilişkin hükümler uygulanmaz:

a) Tüketici hakem heyetinin görevi kapsamında olan uyuşmazlıklar

b) Tüketici hakem heyeti kararlarına yapılan itirazlar

c) 73 'üncü maddenin altıncı fikrasında belirtilen davalar

ç) 74 'üncü maddede belirtilen davalar

d) Tüketici işlemi mahiyetinde olan ve taşınmazın aynından doğan uyuşmazlıklar

(2) 07.06.2012 tarihli ve 6325 sayıl Hukuk Uyuşmazlıklarında Arabuluculuk Kanununun 18/A maddesinin on birinci fikrası tüketici aleyhine uygulanmaz.

(3) Arabuluculuk faaliyeti sonunda taraflara ulaşılamaması, taraflar katılmadiğ iç̧in görüşme yapılamaması veya tarafların anlaşmaları ya da anlaşamamaları hâlinde tüketicinin ödemesi gereken arabuluculuk ücreti, Adalet Bakanlı̆̆ bütçesinden karşılanır. Ancak belirtilen hâllerde arabuluculuk ücreti, Arabuluculuk Asgari Ücret Tarifesinin eki Arabuluculuk Ücret Tarifesinin Birinci Kısmına göre iki saatlik ücret tutarını geçemez.

30 Akipek/Yıldırım/Ermenek /Kutlay, s.127; “ “...kanımızca, ticari davalardan farklı olarak İcra ve Iflas Kanunu’nda düzenlenen ve tüketici mahkemesinin görev alanına giren davalar bakımından da arabulucuya başvuru zorunludur...". 
(4) Arabuluculuk faaliyeti sonunda açılan davanın tüketici lehine sonuçlanması hâlinde arabuluculuk ücreti, 6183 sayılı Kanun hükümlerine göre davalıdan tahsil olunarak bütçeye gelir kaydedilir" ifadesini taşımaktadır" 31.

Tüketici uyuşmazlıklarında zorunlu arabuluculuğun kapsamına ilişkin getirilen bu düzenlemenin, iş ve ticari uyuşmazlıklardaki zorunlu arabuluculuk düzenlemelerinden farklı olduğu görülmektedir. Tüketici uyuşmazlıklarında uyuşmazlığın kapsamı uyuşmazlığın niteliğine göre değil, uyuşmazlığın görüleceği mahkemeye göre belirlenmiştir. Oysa İş uyuşmazlıklarında zorunlu arabuluculuğun düzenlendiği İş Mahkemeleri Kanunu’nda; “Kanuna, bireysel veya toplu iş sözleşmesine dayanan işçi veya işveren alacağı ve tazminatı ile işe iade talebiyle açılan davalarda..." arabulucuya başvurulmuş olması dava şartı olarak belirlenmiştir (İş. Mah. K.m.3/1). $\dot{I}_{s ̧}$ kazası veya meslek hastalığından kaynaklanan maddi ve manevi tazminat ile bunlarla ilgili tespit, itiraz ve rücu davalarının ise, zorunlu arabuluculuk kapsamı dışında tutulduğunu görüyoruz. Ticari uyuşmazlıklarda da benzer bir düzenleme ile tüketici hukukundan farklı olarak, “Bu Kanun'un 4. Maddesinde ve diğer kanunlarda belirtilen ticari davalardan konusu bir miktar paranın ödenmesi olan alacak ve tazminat talepleri hakkında dava açılmadan önce arabulucuya başvurulmuş olması dava şartı olarak belirlenmiştir (TTK.m.5A/I) ${ }^{32}$.

Tüketici uyuşmazlıkları için getirilen "Tüketici mahkemelerinde görülen uyuşmazlıklarda dava açılmadan önce arabulucuya başvurulmuş olması dava şartıdır" (TKHK.m.73/A-1) hükmü gereği, öncelikle tüketici mahkemelerinin görev alanına giren uyuşmazlıkların tespiti gerekir. Bir uyuşmazlıkta gerek Tüketicinin Korunması Hakkında Kanun'un uygulama alanının belirlenmesi gerekse tüketici mahkemelerinin görev alanının belirlenmesi "tüketici işlemi” ve "tüketiciye yönelik uygulamalar” kriterlerine göre tespit edilir. Zira TKHK.m.73/1 uyarınca "Tüketici işlemleri ile tüketiciye yönelik uygulamalardan doğabilecek olan uyuşmazlıklara ilişkin davalarda tüketici mahkemeleri görevlidir”. Yine Kanun'un 2. maddesi de "Bu Kanun, her türlü tüketici işlemi ile tüketiciye yönelik uygulamaları kapsar" ifadesi ile tüketici hukukunun kapsamını belirlemektedir. Dava şartı arabuluculuğun tüketici mahkemelerinin görev alanına giren her türlü uyuşmazlığı kapsaması özellikle tüketici işlemi ve tüketici uygulamaları kavramlarının doğru tespit edilmesi gerekliliğini doğurmaktadır. Kanaatimizce uygulamada arabuluculuğun başarılı sonuçlara ulaşabilmesi, uzman arabulucuların tüketici hukukundaki temel kavramlar hakkında kapsamlı bilgiye sahip olmaları, iyi özümsemeleri ve özellikle zayıf taraf olup korunması gereken tüketiciyi aydınlatma yükümlülüklerini sağlıklı bir

31 TKHK'a eklenen geçici 2. madde ile dava şartı arabuluculuğa ilişkin hükümlerin, yürürlüğe girdiği 28.07.2020 tarihi itibariyle, ilk derece mahkemeleri, bölge adliye mahkemeleri ile Yargıtay'da görülmekte olan davalara (derdest davalar) uygulanmayacağı hükme bağlanmıştır.

32 İş ve ticari uyuşmazlıklarda zorunlu arabuluculukla ilgili karşılaştırmalı ayrıntılı bilgi için bkz.; Ekmekçi, Ömer/Özekes, Muhammet/ Atalı, Murat / Seven, Vural. Hukuk Uyuşmazlıklarında Arabuluculuk, 2. Bası, Ankara, 2019, s.129 vd.; bu konuda eleştirisel bakış için bkz.; Özekes, Muhammet. Tüketici Uyuşmazlıklarında Zorunlu Arabuluculuk, 1. Bası, İstanbul, 2021, e-kitap, erişim tarihi 08.05.2021,11.27, https://ekitap.hukukegitim.com/kitapoku.aspx?id=453, s.19: “...burada dikkat çeken husus, kanun koyucunun zorunlu arabuluculuk konusunda kafasının karışık olduğudur, üç ayrı zorunlu arabuluculuk türü, üç ayrı ifade ile ve hem de kapsamlarla da farklılık oluşturacak şekilde düzenlenmiştir. Bu da daha önce ciddi şekilde düşünüp tartışılıp değerlendirilmeden düzenleme yapıldı̆̆ını, keza zorunlu arabuluculuk konusunda uyumun gözetilmediğini, amacın doğru tespit edilip ona göre çerçeve çizilmediğini göstermektedir. Bunun temelinde yatan sebep ise, arabuluculuğun temel yaklaşım ve ilkelerinin gözardı edilmesidir...". 
şekilde yerine getirmelerine bağlıdır. Bu kapsamda öncelikle "tüketici işlemi” ve "tüketici uygulamaları" kavramlarına değinmek gerekmektedir.

\section{a. Tüketici İşlemi}

Tüketici işlemi kavramı TKHK.m.3/I bendinde, "Tüketici işlemi: Mal veya hizmet piyasalarında kamu tüzel kişileri de dâhil olmak üzere ticari veya mesleki amaçlarla hareket eden veya onun adına ya da hesabına hareket eden gerçek veya tüzel kişiler ile tüketiciler arasında kurulan, eser, taşıma, simsarlık, sigorta, vekâlet, bankacılık ve benzeri sözleşmeler de dâhil olmak üzere her türlü sözleşme ve hukuki işlem" olarak tanımlanmıştır. Madde metninden de anlaşıldığ1 üzere, tüketici işlemi ve bunun sonucu olarak tüketici mahkemelerinin görev alanı oldukça geniş tutulmuştur $^{33}$. Tüketici mahkemeleri adeta bir torba mahkeme haline gelmiştir ${ }^{34}$. Bir başka deyişle, bir uyuşmazlığın tüketici işlemi olması veya tüketiciye yönelik uygulamalardan doğması halinde tüketici mahkemeleri görevlidir. Uyuşmazlığın tüketici işlemi olarak kabul edilebilmesi için ise, aranan kriter, uyuşmazlık konusu sözleşmenin kanunda düzenlenmiş olup olmaması değil, sözleşmenin taraflarıdır. Uyuşmazlık konusu sözleşme, satış, eser, hizmet, vekalet gibi Türk Borçlar Kanunu'nda düzenlenen bir sözleşme olabileceği gibi, Türk Ticaret Kanunu'nda düzenlenen sigorta, yük veya eşya taşıma sözleşmesi veya karma nitelikli bir sözleşme de olabilir $^{35}$. Maddede sayılan sözleşme tipleri örneklendirme mahiyetinde olup, tahdidi olarak belirtilmemiştir ${ }^{36}$.

Tüketici işlemi hem tüketici sözleşmelerini hem de belirli öğeleri bünyesinde barındırması halinde tek taraflı işlemleri kapsar ${ }^{37}$. Tüketici işlemi, tüketici sözleşmelerini de içine alan geniş bir kavramdir $^{38}$. Kanun koyucunun, tüketici işleminin belirlenmesinde getirdiği esas kriter uyuşmazlığın taraflarıdır. Uyuşmazlığın tüketici işlemi olarak kabul edilebilmesi için, taraflarından birinin, ticari veya mesleki olmayan amaçlarla hareket eden gerçek veya tüzel kişi tüketici $^{39}$, diğer tarafın ise, satıc1-sağlayıcı-kredi veren-finansman sağlayan gibi ticari ve mesleki

33 Gümüş, Alper. “6502 Sayılı Tüketicinin Korunması Hakkında Kanuna Genel Bir Bakış”, Sektörel Bazda Tüketici Hukuku ve Uygulamaları (2014-2015), Editörler; Av. Hakan Tokbaş, Fehim Üçışık, 4. Tüketici Hukuku Kongresi, Ankara, 2015, s.20,21.; Özekes, 2021, s.22.

34 Eleştirisel benzer görüş için bkz; Özekes, 2021, s.22.

35 Bu kapsamda misal olarak, vekalet sözleşmesi çerçevesinde taraflardan birinin avukat olduğu bir sözleşmeden doğan uyuşmazlıklar sözleşmenin karşı tarafina göre farklı mahkemelerde çözüme kavuşturulacaktır. Mesela müvekkilinin boşanmak isteyen bir ev hanımı olduğu durumlarda, vekalet ücreti ile ilgili bir uyuşmazlık çıktığında bu uyuşmazlık ev hanımı tüketici olduğu için tüketici işlemi sayılarak tüketici mahkemelerinin görev alanına girecek, ancak müvekkilinin avukatlığını yaptığı, ticaret şirketi olduğu, durumlarda ticaret şirketinin tüketici sıfatı olmadığ1 (mesleki veya ticari amaç güttüğü)için, bu bir tüketici işlemi olmayıp, tüketici mahkemelerinin de görev alanına giremeyecektir; görüldüğü gibi sözleşmenin niteliğine değil, taraflarının tüketici ya da satıcı/sağlayıcı olup olmamasına göre, tüketici işlemi tespit edilmektedir, Koçyiğit /Yeşilkaya, s.518, Gümüş, 20.

36 Gümüş, s.21, Aslan, s.5 vd., Akipek/Yıldırım/Ermenek /Kutlay, s.38.

37 Akipek Öcal, Şebnem. "6502 sayılı Tüketicinin Korunması Hakkında Kanun Kapsamında Tüketici İşlemi ve Usul Hukuku Bakımından Etkileri”, Tüketici Hukukunda Uyuşmazlık Çözümüne İlişkin Güncel Sorunlar ve Çözüm Önerileri Sempozyumu, Editör, Ertan Yardım, Seçkin Yayınları, Ankara, 2018, s. 20-21, Akipek/Yıldırım /Ermenek /Kutlay, s.37.

38 Kara, İlhan. Yeni Kanuna Göre Tüketici Hukuku, Ankara, 2015, s.137.

39 Kanun koyucu tarafından "Tüketici: Ticari veya mesleki olmayan amaçlarla hareket eden gerçek veya tüzel kişi”, olarak tanımlanmıştır (TKHK.m.3 /I-k). 
amaçlarla hareket eden gerçek veya tüzel kişi olması ${ }^{40}$, ayrıca uyuşmazlık konusunun da TKHK.' da tanımlanan mal ve hizmete ilişkin olması gerekir ${ }^{41}$.

Taraflardan birinin tüketicinin oluşturduğu işlemler ile ilgili diğer kanunlarda düzenleme olması, bu işlemin tüketici işlemi sayılmasını ve bu Kanunun görev ve yetkiye ilişkin hükümlerinin uygulanmasını engellemez (TKHK.m.83/2) 42 $^{4}$ Görüldüğü üzere, tüketici işlemi açısından iki tarafın zıt amaçla hareket etmesi söz konusudur. Tüketicinin kâr elde etme amacı olmaksızın yani ticari ve mesleki olmayan bir amaçla hareket etmesi gerekirken, işlemin karşı tarafının yani satıcı ya da sağlayıcının ticari veya mesleki amaçla hareket etmesi gerekir ${ }^{43}$. Kanunda tanımlardan satıcı

40 Sağlayıcı: Kamu tüzel kişileri de dâhil olmak üzere ticari veya mesleki amaçlarla tüketiciye hizmet sunan ya da hizmet sunanın adına ya da hesabına hareket eden gerçek veya tüzel kişiyi (TKHK.m.3/I-1),

Satıc1: Kamu tüzel kişileri de dâhil olmak üzere ticari veya mesleki amaçlarla tüketiciye mal sunan ya da mal sunanın adına ya da hesabına hareket eden gerçek veya tüzel kişiyi (TKHK.m.3/I-i),

Üretici: Kamu tüzel kişileri de dâhil olmak üzere tüketiciye sunulmuş olan mal ya da bu malların hammaddelerini yahut ara mallarını üretenler ile mal üzerine markasını, unvanını veya herhangi bir ayırt edici işaretini koyarak kendisini üretici olarak gösteren gerçek veya tüzel kişiyi (TKHK..m.3/I-i),

Kredi veren: Mevzuatı gereği tüketicilere kredi vermeye yetkili olan gerçek veya tüzel kişiyi, (TKHK..m.3/I-i). ifade eder. Bu düzenlemeler çerçevesinde, karşı taraf tüketici olması koşuluyla, kamu tüzel kişileri de özel hukuk işlemlerinde satıcı, sağlayıcı olarak tüketici işlemi yapabilirler. Elektrik, su, doğalgaz abonelikleri de bu faaliyetlerdendir.

41 Hizmet: Bir ücret veya menfaat karşıllğında yapılan ya da yapılması taahhüt edilen mal sağlama dışındaki her türlü tüketici işleminin konusunu (TKHK.m.3/I-d), ifade eder. Mal: Alışverişe konu olan; taşınır eşya, konut veya tatil amaçlı taşınmaz mallar ile elektronik ortamda kullanılmak üzere hazırlanan yazılım, ses, görüntü ve benzeri her türlü gayri maddi malları ifade eder. (TKHK.m.3/I-h).

42 İstanbul BAM 12. HD. 03.06.2020, E. 2018/1649 K. 2020/545; “...28.05.2014 tarihinde yürürlüğe giren 6502 Sayll Tüketicinin Korunması Hakkindaki Kanununu 3/1-k maddesinde Tüketici "Ticari veya mesleki olmayan amaçl hareket eden gerçek veya tüzel kişi" olarak 3/1- - -bendinde ise Tüketici işlemi "Mal veya hizmet piyasalarında kamu tüzel kişileri de dâhil olmak üzere ticari veya mesleki amaçlarla hareket eden veya onun adına ya da hesabına hareket eden gerçek veya tüzel kişiler ile tüketiciler arasında kurulan, eser, taşıma, simsarllk, sigorta, vekâlet, bankactlı ve benzeri sözleşmeler de dâhil olmak üzere her türlü sözleşme ve hukuki işlem " olarak tanımlanmış, "Temel ilkeler" başllklı 4/5 m. ise "Tüketicinin yapmış olduğu işlemler nedeniyle knymetli evrak niteliğinde sadece nama yazll ve her bir taksit ödemesi için ayrn ayrı olacak şekilde senet düzenlenebilir. Bu fikra hükümlerine aykir olarak düzenlenen senetler tüketici yönünden geçersizdir." şeklinde düzenlenmişstir. Aynı Kanun'un 73/1 madde ve fikrasinda da tüketici işlemleri ile tüketiciye yönelik uygulamalardan doğabilecek uyuşmazliklara ilişkin davalara bakma görevinin tüketici mahkemelerine ait olduğu, 83. maddesinde ise, taraflardan birinin tüketici olduğu işlemler ile ilgili diğer kanunlarda düzenleme olmasinın, bu işlemin tüketici işlemi sayılmasını ve bu kanunun görev ve yetkiye ilişkin hükümlerinin uygulanmasın engellemeyeceği belirtilmiştir. Somut olayda, Bakırköy 6. Asliye Hukuk Mahkemesi'nin 2017/337 Esas 2017/699 Karar sayll dosyast ile davada ticaret mahkemesi görevli olduğu gerekçesiyle görevsizlik kararı verilmiş olup, taraflarca istinaf edilmeden kesinleşen bu görevsizlik kararı ile mahkeme bağll olmayı kamu düzenine iliş̧kin görev hususu resen her aşamada değerlendirilmelidir. Davalı tarafça sunulan delillere göre dava konusu bonolarnn davacının tarafi olduğu Satış Vaadi Sözleşmesi uyarınca düzenlenen sıralı bonolar olduğu tespit edilmiş olup, bu durumda davacı tüketici sıfatın haiz ve söz konusu işlem tüketici işlemi olduğunun kabulü gerekmişstir. Bu itibarla, tüketici konumundaki davacı tarafindan cirantaya karşı açılan işbu davada tüketici mahkemesi görevlidir. (İstanbul BAM 12. HD. E: 2020/221 K: 2020/234). Buna göre mahkemece görev konusunda bir inceleme yapllmaksızın işin esasına girilerek karar verilmesi doğru bulunmamıştır. ..." (Kazancı İçtihat Bilgi Bankası)

43 Yargıtay içtihatlarında sıklıkla görüldüğü üzere, tüketici işlemi açısından ticari veya mesleki amaç kavramının varlığı tüketicinin güçsüz konumda olup korunması gerekliliğgi ilkesi çerçevesinde satıcının değil alıcının amacına göre belirlenmelidir; YHGK. 22.11.2018, E. 2017/13-1982 K. 2018/1752; "Davacının Almanya'da iş̧̧i olarak çallş̧tı̆̆ ve burada kazandığı birikimlerle memleketinde kendisi için üç, babası için iki daireyi satın aldığı durumda bu işlemin özel ihtiyaçlar için nihai tüketim gayesi ile yapıldı̆̆ hususu dosyaya yansımamıştır. Bu halde gerçekleşen hukuki işlemin tüketici hukukunun koruduğu anlamda tüketici işlemi olarak kabul edilmesi mümkün olmadığından uyuşmazlığın genel mahkemelerin görev alanı içerisinde kaldı̆̆l...Tüketici işlemi yönünden belirleyici olan, satın alınan mal veya hizmetin saylst veya bedeli değil, tüketicinin, mal veya hizmeti satın alırken ticari veya mesleki amaç ile hareket etmemesi ve yine, kendi ihtiyacı için kullanması ya da tüketmesidir...”. YHGK. 2020, E. 2017/19-1637 K. 2020/13 (Koçyiğit/Yeşilkaya, s.542); "Davac1 limited şirket, tacir olup, tüzel 
ve sağlayıcı arasındaki ayrımın tüketiciye sunulan mal veya hizmet olarak belirlendiği anlaşılmaktadır. Tüketici, gerçek kişi ya da dernek, vakıf gibi ticari veya mesleki amaç gütmeyen tüzel kişi de olabilir ${ }^{44}$. Önemli olan ticari ya da mesleki amaçla hareket etmemektir ${ }^{45}$. Mesela gerçek kişi tüketiciler açısından kişisel veya ailevi ihtiyaçların karşılanması amacıyla yapılan işlemler, tüzel kişilerde ise tüzel kişinin mesleki faaliyetleri dışındaki ihtiyaçların karşılanması amacıyla yapılan işlemler tüketici işlemidir ${ }^{46}$. Tüketici işleminin diğer tarafı ise, tam zit bir amaç çerçevesinde yani tüketiciye ticari ve mesleki amaçlarla mal ve hizmet sunan ya da sunanın adına veya hesabına hareket eden gerçek ve tüzel kişidir ${ }^{47}$.Satıcı ve sağlayıcılar dernekler, vakıflar, ticaret şirketleri gibi özel hukuk tüzel kişileri olabileceği gibi kamu hukuku tüzel kişileri de olabilir. Kamu iktisadi teşebbüsleri tarafından tüketiciye sunulan akaryakıt, doğalgaz, elektrik, su gibi mallar, haberleşme, ulaşım, taşıma vb. hizmetler bu kapsamdadır ${ }^{48}$. Satıcı veya sağlayıcı, mal

kişilik adına ticari işletmesinde kullanmak üzere otomobil satın almıştır. Davacı tüketici olarak tanımlanamayacă̆ gibi, yaptığı işlemin de tüketici işlemi olarak kabulüne de olanak bulunmamaktadır.".

$44 \mathrm{Bu}$ konudaki tek istisna kanun koyucu tarafından paket tur sözleşmeleri (TKHK..m.51/9) açısından getirilmiștir. Ticari veya mesleki faaliyeti çerçevesinde paket tur hizmetinden yararlanan kişi gerçek ya da tüzel kişi olmasına bakılmaksızın tüketici olarak kabul edilir. ANKARA BAM 4. HD. 10.03.2017, E. 2017/201 K. 2017/218; “...Somut olayda davanın hukuki niteliği, 6502 sayll Tüketicinin Korunması Hakkında Kanun'un (TKHK) 51. maddesinde düzenlenmiş olan "paket tur" niteliğindeki sözleşme ilişkisinden kaynaklanmaktadır. Taraflar arasındaki sözleşmenin yazılı şekilde yapılmamış olmasının da sonuca etkisi bulunmamaktadır. 6502 sayılı Kanun'un 51. maddesinde tanımlandı̆̆ üzere paket tur sözleşmeleri, paket tur düzenleyicileri veya aracıları tarafindan ulaştırma, konaklama ve diğer turizm hizmetlerinden en az ikisinin birlikte verildiği, her şeyin dâhil

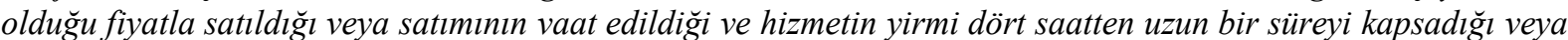
gecelik konaklamayı içerdiği sözleşmelerdir. Aynı maddenin 10. fikrasında da, bu sözleşmelerle ilgili ön bilgilendirme, sözleşmenin içeriği, paket turun devri, sözleşmede değişiklik yapılmasının koşulları ve bu hâllerde tüketicinin haklarl, paket turun iptal edilmesinin sonuçları, paket tur düzenleyicisinin ve aracısının sorumlulukları, tüketicinin hangi hallerde tazminat talep edebileceği, sözleşmeden dönme ve sonuçlart ile diğer uygulama usul ve esaslarının yönetmelikle belirleneceği belirtilmiş olup, 28.05.2014 tarihinde yürürlüge giren 6502 sayll TKHK kapsamında çıkarılan "Paket Tur Sözleşmeleri Yönetmeliği”" de 14.1.2015 tarih ve 29236 sayılı Resmi Gazete'de yayınlanarak yürürlüğe girmiştir. Taraflar arasındaki uyuşmazlık, 6502 sayılı Tüketicinin Korunması Hakkında Kanun kapsamında düzenlenen paket tur sözleșmesinden kaynaklandığına göre, davaya bakmaya tüketici mahkemesi görevlidir. Söz konusu Kanun'da "tüketici”, "Ticari veya mesleki olmayan amaçlarla hareket eden gerçek veya tüzel kişi” "şeklinde tanımlanmış olup, davalının gerçek kişi olmayıp, dernek statüsünde bir tüzel kişi olması da sonucu değiştirmez. Kaldı ki Aynı Kanun'un 51/9. maddesinde paket tur sözleşmelerine münhasır olmak üzere, "tüketici" kavramı daha geniş olarak düzenlenmiş olup, ticari veya mesleki faaliyetleri çerçevesinde paket tur hizmetinden faydalanan kişiler de tüketici olarak kabul edilmiştir. Dolayıslyla davacı Derneğin, dava konusu paket tur hizmetinden ticari ya da mesleki amaçlarla faydalanıp faydalanmadı̆̆ da görevli mahkemenin belirlenmesi konusunda sonuca etkili değildir. Yine, her ne kadar dava, daha önce Asliye Ticaret Mahkemesinde açılmış ve bu mahkemenin verdiği görevsizlik kararını müteakip dava dosyası Asliye Hukuk Mahkemesine gelmiş ise de daha önce (asliye hukuk mahkemesinin görevli olduğu gerekçesiyle) verilen görevsizlik kararı, kanun yolu incelemesinden geçmeden kesinleşmiş olduğundan, bağlayıcı değildir. Açıklanan tüm bu nedenlerle; tarafların sıfatına, dava konusu paket tur sözleşmesinin 6502 sayıl Tüketicinin Korunması Hakkında Kanun'da ayrıca düzenlenmiş olmasına ve yine aynı Kanun'un 73. maddesi gereğince, tüketici işlemleri ile tüketiciye yönelik uygulamalardan doğabilecek uyuşmazlıklara ilişkin davalarda tüketici mahkemelerinin görevli olduğunun kabul edilmiş̧ olmasına göre, iş bu davada da görevli mahkeme, tüketici mahkemesidir. ...” (Lexpera Hukuk Bilgi Sistemi)

45 YHGK. 22.11.2018, E. 2017/13-1982 K. 2018/1752; “Bu temel ölçüt dikkate alındığında; tüketici ișleminden söz edebilmek için hukuki işleme konu olan mal veya hizmetin, tüketici olan alıcının kendisinde kalması, malın ticari hayata geri dönmemesi, ödenen maliyetin geri kazanılmaması, başka bir malın ham maddesi veya yarı mamul maddesi olarak kullanılmaması gerekir Böyle olunca, bir malı olduğu gibi ya da işleyerek bir başkasına satmak veya çıkar karşılı̆̆ devretmek üzere satın alan, yani kendisi de satıcı konumuna girecek olan kişiler tüketici saylmazlar.".

46 Aydoğdu, Murat. Tüketici Hukuku Dersler, Ankara, 2015, s.61 vd

47 Akipek/Yıldırım/Ermenek /Kutlay, s.33, Aydoğdu, s.64, Aslan, s.6.

48 Akipek /Yıldırım/Ermenek /Kutlay, s.35, Aydoğdu, s.64, Aslan, s.6. 
satma veya hizmet sunma faaliyetlerini ivazlı gerçekleştirmelidir. Kazanç sağlama amacının olmadığı, mesela bağışlama sözleşmeleri ya da hatır karşılığı hizmet verilmesi halleri TKHK'un kapsamı dışındadır ${ }^{49}$. Yine TKHK'un amacı ekonomik anlamda güçsüz tarafı korumak olduğuna göre, mesleki faaliyet dışında mal veya hizmet sunan kişiler karşısında, tüketici eşit konumda olduğundan, uyuşmazlıklar genel hükümlere göre çözümlenir ${ }^{50}$.

Tüketici işleminin bir diğer önemli unsuru da işlemin konusunun TKHK'da tanımı yapılan mal ve hizmete ilişkin olmasıdır. Kanun hükmüne göre; hizmet, bir ücret veya menfaat karşılığında yapılan ya da yapılması taahhüt edilen mal sağlama dışındaki her türlü tüketici işleminin konusunu (TKHK.m.3/I-d), mal ise; alışverişe konu olan, taşınır eşya, konut veya tatil amaçlı taşınmaz mallar ile elektronik ortamda kullanılmak üzere hazırlanan yazılım, ses, görüntü ve benzeri her türlü gayri maddi malları ifade eder (TKHK.m.3/I-h). Bu ayrıntılı tanımlardan da anlaşıldığı üzere, mal ve hizmet kavramlarının kapsamı çok geniş tutulmuş, sözleşmenin niteliğine bakılmaksızın, diğer unsurların varlığı halinde neredeyse her türlü sözleşme konusu bu kanun kapsamına dahil edilmiştir ${ }^{51}$.

Netice itibariyle, bir hukuki işlemin tüketici işlemi olarak kabul edilip edilebilmesi için gereken üç temel unsur vardır. Öncelikle taraflardan birinin kanunda belirtildiği üzere, ticari veya mesleki olmayan amaçlarla hareket eden gerçek veya tüzel kişi, yani tüketici olması, hukuki işlemin karşı tarafını ise zıt amaçla bir başka deyişle ticari veya mesleki amaçla hareket eden satıcı, sağlayıcı, üretici gibi bir gerçek veya tüzel kişinin oluşturması gerekir. Ayrıca yapılan işlemin konusunun da kanun çerçevesinde belirlenen mal ya da hizmetin kapsamına girmesi gerekir. Tüketici işleminin tespiti yapılırken her somut olayın kendi içerisinde değerlendirilmesi gerektiği kuralının da göz ardı edilmemesi gerekir. Yine tüketici işleminin tespiti için, sözleşmenin kanunda düzenlenip düzenlenmemesi, sözleşmenin çeşidi, sayıs1 ${ }^{52}$ ya da niteliğinin bir önemi olmayıp, önemli olan bu üç unsurun o somut olaydaki varlığıdır.

\section{b. Tüketiciye Yönelik Uygulamalar}

Tüketicinin Korunması Hakkında Kanunu'nun ikinci maddesinde belirtilen “Bu Kanun, her türlü tüketici işlemi ile tüketiciye yönelik uygulamaları kapsar” ifadesi ile tüketiciye yönelik uygulama kavramının getirilmesi Kanunun kapsamını da genişletmiştir. Bu çerçevede kamu tüzel

49 Aydoğdu, s.64, Aslan, s.8.

50 Örneğin, öğretmen olan bir kişi arkadaşına otomobilini sattığında bu eşitler arası bir ilişki olup tüketici işlemi değildir, uyuşmazlık çıktığında Türk Borçlar Kanunu hükümlerine göre çözümlenir. Ancak bu otomobili alan kişi arkadaşından değil de bir otomobil galerisinden alsaydı o zaman tüketici işlemi olup uyuşmazlık TKHK kapsamında çözümlenecekti. Ayrıntılı bilgi için bkz.; Aydoğdu, s.65, Narbay, Şafak/Akkuş, Muhammed. "Ticari İş ve Tüketici İşlemi Kavramları Ekseninde Görevli Mahkeme Ve Dava Şartı Arabuluculuk Üzerine Düşünceler", TAAD., Y.11, S.44, Ekim,2020, s.313 vd.

51 Aslan, s.8.

52 Ancak Yargıtay bazı kararlarında satıma konu nesnelerin sayı ve miktarlarını dikkate alarak tüketim ya da yatırım amaçlı hareket edildiği sonucuna varmıştır. Örneğin bir kararında; "Davacının 17 adet tatil amaçlı devre mülkü tüketim için satın aldığı söylenemez" ifadesi ile tüketici sıfatının olmadığını belirtmiştir (Yargıtay, 13.HD., 20.01.2015, E.2014/47555 K.2015/907) Yine arsa sahibinin arsa payı karşıllı̆ inşaat özleşmesine dayanarak yüklenici aleyhine açtığı akdin feshinin tespiti davasının tüketici mahkemelerinde değil genel mahkemede görülmesi gerektiğine karar vermiştir (Yargıtay, 23.HD., 20.03.2015, E.2014/10132 K.2015/1800) Ayrıntılı bilgi için bkz.; Tutumlu, Mehmet Akif. "Tüketici Uyuşmazlıkları Açısından Tüketici Kavramı ve bu Kavramın Kapsadığı Kişiler, 5. Tüketici Hukuku Kongresi, Sektörel Bazda Tüketici Hukuku ve Uygulamaları 2015-2016, Editörler, Tokbaş,Hakan/Üçışık, Fehim, Ankara,2016, s.572 vd. 
kişileri de dahil olmak üzere ticari ve mesleki amaçla hareket eden veya onun adına ya da hesabına hareket eden gerçek veya tüzel kişilerin, tüketicilerle sözleşme imzalanmasından önce, sözleşmenin kurulması sırasında ve sözleşme imzalandıktan sonra yaptıkları uygulamalar da kanun kapsamına alınmıştır ${ }^{53}$.

Tüketiciye yönelik uygulama kavramı ile sözleşme öncesinde tüketicinin aldatıcı reklamlara ve ticari uygulamalara karşı korunması amaçlanmış, sözleşme öncesi görüşmelerden sorumluluk anlamına gelen "culpa in contrahendo" sorumluluğu yasal bir zemine kavuşmuştur ${ }^{54}$. Sözleşmenin yapılması sırasında aydınlatma yükümlülügü, garanti belgesi, tanıtma ve kullanma k1lavuzu verme zorunluluğu, sözleşme yapma zorunluluğu (doğalgaz, internet, elektrik vs.), sözleşmenin yapılmasından sonra o mala ilişkin satış sonrası hizmetler tüketiciye yönelik uygulama olarak belirtilmiş, nihai olarak tüketicinin korunması amaçlanmıştır.

$\mathrm{Bu}$ açıklamalardan da anlaşıldığı üzere, tüketici işlemleri ile tüketiciye yönelik uygulamalardan doğan uyuşmazlıklar tüketici mahkemelerinin görev alanındadır. 6502 sayılı TKHK'nun 73/A maddesine göre, bu uyuşmazlıklar dava şartı arabuluculuk kapsamındadır. Dava açılmadan önce arabulucuya başvuru yapılarak sürecin anlaşmazlıkla sonuçlanması ve anlaşmama tutanağının dava dilekçesine eklenerek dava açılması dava şartıdır. Madde hükmünde dava şartı arabuluculuğa tabi uyuşmazlıkların kapsamı oldukça geniş olarak düzenlenmekle beraber, birçok istisnanın da getirildiği de görülmektedir.

\section{Tüketici Uyuşmazlıklarında Arabuluculuğa Başvuru Zorunluluğunun İstisnaları}

Tüketici uyuşmazlıklarında dava açılmadan önce arabuluculuğa başvurulmuş olması dava şartı olarak düzenlenmiş olmakla birlikte, bazı uyuşmazlıklar bu zorunluluk kapsamında değildir.

Dava şartı arabuluculuk başlığını taşıyan, TKHK. md. 73/A hükmüne göre;

“Tüketici mahkemelerinde görülen uyuşmazlıklarda dava açılmadan önce arabulucuya başvurulmuş olması dava şartıdır. Ancak,

a) Tüketici hakem heyetinin görevi kapsamında olan uyuşmazlıklar

b) Tüketici hakem heyeti kararlarına yapılan itirazlar

c) 73 'üncü maddenin altıncı fikrasında belirtilen davalar

ç) 74'üncü maddede belirtilen davalar

d) Tüketici işlemi mahiyetinde olan ve taşınmazın aynından doğan uyuşmazlıklarda, dava şartı olarak arabuluculuğa ilişkin hükümler uygulanmaz”.

53 TKHK.'nun 2. maddesinin gerekçesinde kapsamla ilgili ayrıntılı açıklama yer almaktadır; “Kanunun kapsamının belirlendiği ikinci maddede "tüketici işlemlerinin" ve "uygulamaların" kapsam dâhilinde olduğu belirtilmiştir. Böylece, kamu tüzel kişileri de dâhil olmak üzere ticari veya mesleki amaçlarla hareket eden veya onun adına ya da hesabına hareket eden gerçek veya tüzel kişilerin, tüketicilerle sözleşme imzalanmadan önce, sözleşmenin kurulması esnasında ve sözleşme imzaladıktan sonra yaptıkları uygulamalar da Kanun kapsamında değerlendirilecektir. Örneğin, tüketici kredisi verilmeden önce tüketicilere verilmesi öngörülen sözleşme öncesi bilgi formu, devre tatil sözleşmesinin kurulması esnasındaki satış yöntemi veya bir malın satışından sonra o mala ilişkin satış sonrası hizmetler gibi uygulamalar konusunda çıkabilecek uyuşmazlıklara bu Kanun hükümleri uygulanacaktır. Bu hüküm ile özellikle bir hukuki işleme veya sözleşmeye dayanmayan, tüketiciye yönelik haksız ticari uygulamaların da Kanun kapsamında olduğu açıklığa kavuşturulmuş olmaktadır.”.

54 Zevkliler/ Özel, s.88, Aydoğdu, s.96 vd.. 
$\mathrm{Bu}$ istisnaların ayrı ayrı incelenmesi konunun anlaşılabilmesi için yararlı olacaktır.

\section{a. Tüketici Hakem Heyetinin Görevi Kapsamında Olan Uyuşmazlıklar}

Tüketicinin Korunması Hakkındaki Kanun, tüketici uyuşmazlıklarının çözümü bakımından dava konusunun değerine göre tüketici mahkemeleri ile tüketici hakem heyetleri olarak iki görevli merci belirlemiştir. Öncelikle tüketici hakem heyetlerinin kuruluş ve oluşumu düzenlendikten sonra ${ }^{55}$, tüketici işlemleri ile tüketiciye yönelik uygulamalardan kaynaklanan ve belirli bir parasal sınırı aşmayan uyuşmazlıklarda tüketici hakem heyetlerine başvuru zorunlu tutulmuştur. Bu parasal sınırların ${ }^{56}$ üzerindeki uyuşmazlıklarda ise, tüketici hakem heyetlerine değil tüketici mahkemelerine dava açılması gerekir. Parasal sınırın altında kalan uyuşmazlıklarda tüketici hakem heyetine gidilmeksizin dava açılması halinde, davanın mahkemece dava şartı yokluğu nedeniyle reddedilmesi gerekir ${ }^{57}$. Tüketici hakem heyetlerinin hukuki niteliği öğretide tartışmalı olmakla birlikte kararlarının bağlayıcı olması da dikkate alındığında zorunlu tahkim görüşü ağır basmaktadır ${ }^{58}$.

55 TKHK.m.66- (1) Bakanlık, tüketici işlemleri ile tüketiciye yönelik uygulamalardan doğabilecek uyuşmazlıklara çözüm bulmak amacıyla il merkezlerinde ve yeterlilik şartları yönetmelikle belirlenen ilçe merkezlerinde en az bir tüketici hakem heyeti oluşturmakla görevlidir.

(2) Başkanlığı illerde ticaret il müdürü, ilçelerde ise kaymakam veya bunların görevlendireceği bir memur tarafindan yürütülen tüketici hakem heyeti;

a) Belediye başkanının konunun uzmanı belediye personeli arasından görevlendireceği bir üye,

b) Baronun, mensupları arasından görevlendireceği bir üye,

c) Satıcının tacir olduğu uyuşmazlıklarda ticaret ve sanayi odasının ya da bunların ayrı ayrı örgütlendiği yerlerde ticaret odasının; satıcının esnaf ve sanatkâr olduğu uyuşmazlıklarda, illerde esnaf ve sanatkârlar odaları birliğinin, ilçelerde ise en fazla üyeye sahip esnaf ve sanatkârlar odasının görevlendireceği bir üye,

ç) Tüketici örgütlerinin kendi aralarından seçecekleri bir üye,

olmak üzere başkan dâhil beş üyeden oluşur. Başkan ve üyelerin bu fikrada yer alan niteliklere sahip yedekleri de ayrıca belirlenir. (Ek cümleler: 11.07.2020-7249/26 md.) Birden fazla baro kurulan illerde il ve ilçe tüketici hakem heyetlerine üye görevlendirilmesi, baroların eşit ve dönüşümlü temsili esas alınarak yapılır. Görevlendirmeye ilişkin usul ve esaslar Türkiye Barolar Birliği tarafından hazırlanan yönetmelikte gösterilir. (3) Tüketici hakem heyetinin oluşumunun sağlanamadığı yerlerde noksan üyelikler, yönetmelikle belirlenen üyelik niteliklerine sahip Devlet memurları arasından illerde ticaret il müdürü, ilçelerde ise kaymakam tarafından tamamlanır.

TKHK.m.67- (1) Raportörler il ve ilçe merkezlerinde kurulu bulunan tüketici hakem heyetlerinde istihdam edilebilir. Raportör sayısının yeterli olmadığı illerde ticaret il müdürü tarafından ticaret il müdürlüğü personeli arasından, ilçelerde ise kaymakam tarafından ilçede görevli Devlet memurları arasından yeterli sayıda raportör görevlendirilir.

(2) Tüketici hakem heyeti raportörleri, heyetin çalışmalarına ve kararlarına esas olacak dosyaları hazırlamak ve uyuşmazlığa ilişkin raporu sunmakla görevlidir.

$56 \mathrm{Bu}$ maddede yer alan parasal sinırların 01.01.2021 tarihinden itibaren uygulanması ile ilgili olarak 29.12.2020 tarihli ve 31346 sayılı Resmî Gazete'de yayımlanan Ticaret Bakanlığının "6502 Sayılı Tüketicinin Korunması Hakkında Kanunun 68'inci ve Tüketici Hakem Heyetleri Yönetmeliğinin 6'nc1 Maddelerinde Yer Alan Parasal Sınırların Artırılmasına İlişkin Tebliğin” 3. maddesine göre; (1) 2021 yılı için Tüketici Hakem Heyetlerine yapılacak başvurularda değeri: a) 7.550 (yedibinbeşyüzelli) Türk Lirasının altında bulunan uyuşmazlıklarda İlçe Tüketici Hakem Heyetleri b) Büyükşehir statüsünde olan illerde 7.550 (yedibinbeşyüzelli) Türk Lirası ile 11.330 (onbirbinüçyüzotuz) Türk Lirası arasındaki uyuşmazlıklarda İl Tüketici Hakem Heyetleri c) Büyükşehir statüsünde olmayan illerin merkezlerinde 11.330 (onbirbinüçyüzotuz) Türk Lirasının altında bulunan uyuşmazlıklarda Il Tüketici Hakem Heyetleri ç) Büyükşehir statüsünde olmayan illere bağll ilçelerde 7.550 (yedibinbeşyüzelli) Türk Lirası ile 11.330 (onbirbinüçyüzotuz) Türk Lirası arasındaki uyuşmazlıklarda Il Tüketici Hakem Heyetleri görevlidir.

57 Akipek/Yıldırım/Ermenek/Kutlay, s.119.

58 Taşpınar Ayvaz, Sema. "Tüketici Hakem Heyetlerinin Hukuki Niteliği”, Tüketici Hukukunda Uyuşmazlık Çözümüne İlişkin Güncel Sorunlar ve Çözüm Önerileri Sempozyumu, Editör, Ertan Yardım, Seçkin Yayınları, 
Tüketici hakem heyetinin görev alanına giren tüketici işlemi ile tüketiciye yönelik uygulamalardan kaynaklanan uyuşmazlıklarda arabuluculuğa başvuru zorunlu değildir. Ancak hemen belirtelim ki ihtiyari arabuluculuğa başvuru her zaman mümkündür. TKHK.m.68/5 hükmü gereği, tüketicilerin ilgili mevzuatına göre alternatif uyuşmazlık çözüm mercilerine başvurabilirler.

Tüketici işlemleri ile tüketiciye yönelik uygulamalardan kaynaklanan ve değeri belirlenen para sınırının altında kalan uyuşmazlıklar tüketici hakem heyetinin görev alanına girmekle birlikte $^{59}$, tarafların İcra İflas Kanunundan kaynaklanan hakları saklı tutulmuştur (TKHK.m.68/1). Bir başka deyişle, bu uyuşmazlıklarla ilgili olarak hakem heyetlerine başvuru yapılmadan doğrudan icra takibi yapılabilir ${ }^{60}$. Hakem heyetlerinin görev alanına giren bu uyuşmazlıklar için, arabuluculuğa başvuru zorunlu olmasa da hakem heyetlerine başvuru yapılmadan icra takibi yapılması halinde, icra hukuku çerçevesinde takibe itiraz edilerek, tüketici mahkemelerinde itirazın iptali davası, borçtan kurtulma davası ve istirdat davası açılması mümkündür. Bu durumda belirtilen uyuşmazlıkların çözümü tüketici mahkemesinin görev alanında olduğu için, TKHK.m.73/A gereği dava şartı arabuluculuk kapsamında kalacaktır ${ }^{61}$.

Ankara, 2018, s. 47, Atalı, Murat, "Yargılama Illkeleri Çerçevesinde Tüketici Hakem Heyetleri", Tüketici Hukukunda Uyuşmazllk Çözümüne İlişkin Güncel Sorunlar ve Çözüm Önerileri Sempozyumu, Editör, Ertan Yardım, Seçkin Yayınları, Ankara, 2018, s.71.

${ }^{59}$ Yargitay 11. HD., 13.02.2017, E. 2016/14881 K. 2017/776; “...Mahkemece, uyuşmazlikta Ticaret Mahkemesinin görevli olduğu, Tüketici Hakem Heyeti'nin görev alanı dışında kaldı̆̆ gerekçesiyle davanın kabulüne karar verilmiş, karar aleyhine Adalet Bakanlığı'nın yazısı üzerine Yargıtay Cumhuriyet Başsavcllığı tarafindan kanun yararına bozma talebinde bulunulmuştur. Dava, Tüketici Hakem Heyeti kararının iptali istemine iliş̧kindir. 6502 Sayll Tüketicinin Korunması Hakkindaki Kanun'un 3/k maddesinde Tüketicinin "Ticari veya mesleki olmayan amaçlarla hareket eden gerçek veya tüzel kişi” yi ifade ettiği, Yasa'nın 3/1 maddesinde Tüketici İşlemini “mal veya hizmet piyasalarında kamu tüzel kişileri de dahil olmak üzere ticari veya mesleki amaçlarla hareket eden veya onun adına ya da hesabına hareket eden gerçek veya tüzel kişiler ile tüketiciler arasında kurulan eser, taşıma, simsarlık, sigorta, vekalet bankacllık ve benzeri sözleșmelerde dahil olmak üzere her türlü sözleşme ve hukuki işlemi "olarak tanımlandığl, Yasa'nın 66/1 maddesinde "Bakanlığın, tüketici işlemleri ile tüketiciye yönelik uygulamalardan doğabilecek uyuşmazlıklara çözüm bulmak amacryla il merkezlerinde ve yeterlilik şartları yönetmelikle belirlenen ilçe merkezlerinde en az bir tüketici hakem heyeti oluşturmakla görevli" olduğu, Yasa'nın 68/1 maddesinde "değeri 2.000.00 TL'nin altında (karar tarihinde 2.320,00 TL) bulunan uyuşmazllklarda ilçe tüketici hakem heyetlerine ... başvurunun zorunlu" olduğu, Yasa'nın 83/2 maddesinde de "taraflardan birini tüketicinin oluşturduğu işlemler ile ilgili diğer kanunlarda düzenleme olmasının, bu işlemin tüketici işlemi sayllmasinı ve bu kanunun görev ve yetkiye ilişskin hükümlerinin uygulanmasinı engellemeyeceği" düzenlenmiştir. Somut uyuşmazlıkta, hava taşımasının gerçekleşmemesi nedeniyle ödenen bilet bedelinin istirdadı talep edilmekte olup, davalı yolcu 6502 sayll Yasa'nın 3/k maddesinde ifade edilen "tüketici”, davalının işlemi Yasa'nın 3/1 maddesinde ifade edilen "tüketici işlemi", olup Yasa'nın 66 ve 68 maddesi hükümleri gereğince uyuşmazllk 6502 sayıl Y Yasa kapsamında ve Tüketici Hakem Heyeti'nin görev alanı içinde bulunmaktadır. Kaldı ki, 6502 sayılı Yasa'nın 83/2 maddesi açı hükmü de tereddüde yer birakmayacak şekilde somut uyuşmazliğın 6502 sayılı Yasa kapsamında bulunduğunu vurgulamaktadır. Bu durumda, mahkemece, uyuşmazlığın 6502 sayılı Yasa kapsamında kaldiğg, Tüketici Hakem Heyeti'nin uyuşmazlıkta görevli olduğunun kabulü ile işin esasının incelenerek hüküm kurulması gerekirken yazll şekilde karar verilmesi yürürlükteki hukuka aykırl görüldüğ̈̈nden yazıll emir isteğinin kabulü ile hükmün kanun yararına bozulması gerekmişstir. ..." (Kazancı İçtihat Bilgi Bankası)

60 TKHK.m.68/1'de yer alan "Tarafların İcra ve İflas Kanunu'ndaki hakları saklı kalmak kaydiyla" ibaresinin Anayasa'nın 10., 36. ve 172. maddelerine aykırıllı̆̆ ileri sürülerek iptaline karar verilmesi istenmişse de söz konusu ibarenin Anayasa'ya aykırılık teşkil etmediği gerekçesiyle talep reddedilmiştir. (AYM. 14.11.2019, E. 2019/99 K. 2019/83).

61 Akipek /Yıldırım/ Ermenek /Kutlay, s.121, Koçyiğit /Yeşilkaya, s.530., aksi görüş için bkz; Özekes, 2021, s. 32. 


\section{b. Tüketici Hakem Heyeti Kararlarına Yapılan İtirazlar}

İl ve ilçe tüketici hakem heyetinin verdiği kararlar tarafları bağlar (TKHK.m.70/1). Ancak tarafların tüketici hakem heyetlerinin verdiği kararlara karşı, kararın tebliğ tarihinden itibaren on beş gün içinde tüketici hakem heyetinin bulunduğu yerdeki tüketici mahkemesine itiraz hakları vardır. İtiraz, tüketici hakem heyeti kararının icrasını durdurmaz. Ancak talep edilmesi şartıyla hâkim, tüketici hakem heyeti kararının icrasını tedbir yoluyla durdurabilir (TKHK.m.70/3). Tüketici hakem heyeti kararlarına karşı yapılan itiraz üzerine tüketici mahkemesinin vereceği karar ipso iure (yasa gereği) kesindir (TKHK.m.70/5). Bir başka deyişle bu karara karşı temyiz yolu kapalidir ${ }^{62}$.

Tüketici hakem heyetlerinin görev kapsamına giren tüketici işlemleri ve tüketiciye yönelik uygulamalardan doğan uyuşmazlıklar için verilen kararlara karşı yapılan itirazlarla ilgili tüketici mahkemeleri görevli olduğu halde, bu itirazlar dava şartı arabuluculuk kapsamı dışında tutulmuştur (TKHK.m.73/A-1/b). Bir başka deyişle bu konuda bir istisna getirilerek, tüketici hakem heyetleri tarafindan karara bağlanan bir uyuşmazlığa itiraz edilmesi halinde öncelikle arabulucuya gitme zorunluluğu olmaksızın doğrudan tüketici mahkemelerine gidilebilir.

\section{c. TKHK.m.73/6 Kapsamındaki Davalar}

Tüketici örgütleri, ilgili kamu kurum ve kuruluşları ile Bakanlık; haksız ticari uygulamalar ve ticari reklamlara ilişkin hükümler dışında, genel olarak tüketicileri ilgilendiren ve bu Kanuna aykırı bir durumun doğma tehlikesi olan hâllerde bunun önlenmesine veya durdurulmasına ilişkin ihtiyati tedbir kararı alınması veya hukuka aykırı durumun tespiti, önlenmesi veya durdurulması amaciyla tüketici mahkemelerinde dava açabilir (TKHK.m.73/6) ${ }^{63}$.

Kanun hükmünde belirtilen davalar, tüketicilerin kişisel menfaatlerine ilişkin olmayıp, tüketicileri genel olarak ilgilendiren ve tüketici mahkemelerinde açılan davalardır. Bu davalarla amaçlanan kolektif hukuki yararın korunmasıdır ${ }^{64}$. Haksız ticari uygulamalar ile ticari reklam ve ilanlara ilişkin hükümler madde kapsamı dışında bırakılmıştır. Davacı sıfatına sahip olan tüketici örgütleri, ilgili kamu kurum ve kuruluşları ile Bakanlık, topluluk davaları ile, hukuka aykırı durumun tespitini, önlenmesini ve/veya durdurulmasını talep edebilir, ancak maddi ve manevi tazminat talebinde bulunamazlar. $\mathrm{Bu}$ madde ile düzenlenen topluluk davaları da dava şartı arabuluculuk kapsamı dışında bırakılmıştır.

62 Ayrıntılı bilgi için bkz. Tutumlu, Mehmet Akif, “6502 Sayılı TKHK Hükümleri Işığında Tüketici Hakem Heyetlerine İtiraz Davası", Tüketici Hukukunda Uyuşmazlık Çözümüne İlişkin Güncel Sorunlar ve Çözüm Önerileri Sempozyumu, Editör, Ertan Yardım, Ankara, 2018, s.153-171.

63 Madde gerekçesinde “...Altıncı fikrada, tüketici mahkemelerinde tüketicilerin ortak çıkarlarının korunması amacıyla dava açma ehliyetine sahip taraflar tüketiciler, tüketici örgütleri, ilgili piyasayı düzenleyen kamu kurum ve kuruluşları ile Bakanlık olarak belirlenmiştir. Kendilerine dava hakkı verilenler, haksız ticari uygulamalar ile ticari reklam ve ilânlara ilişkin hükümler dışında, münferit tüketici sorunu olmayan ve genel olarak tüketicileri ilgilendiren hallerde dava açabileceklerdir. Örneğin tehlikeli malların piyasadan çekilmesi gibi talepler bu türden genel nitelikli taleplerdir. Dava hakkı sahiplerinin talepleri, bu Kanuna aykırı bir durumun doğma tehlikesi olan hallerde bunun önlenmesine veya durdurulmasına ilişkin ihtiyati tedbir kararı alınması veya hukuka aykırı durumun tespiti, önlenmesi veya durdurulmasına karar verilmesi yönünde olacaktır... "s şeklinde açıklanmıştır.

64 Ayrıntılı bilgi için bkz. Tuğsavul Taşpolat, Melis. "Topluluk Davalarının Tüketicinin Korunması Hakkında Kanun Bakımından Değerlendirilmesi”, Tüketici Hukukunda Uyuşmazlık Çözümüne İlişkin Güncel Sorunlar ve Çözüm Önerileri Sempozyumu, Editör, Ertan Yardım, Ankara, 2018, s.101-118, Aslan, s.59. 


\section{d. TKHK.m.74 Kapsamındaki Davalar}

TKHK.m.73/A hükmüne göre dava şartı arabuluculuk kapsamı dışında bırakılan hususlardan bir diğeri de satışa sunulan seri ayıplı mallar hakkında düzenleme getiren TKHK.m.74 çerçevesinde açılan davalardır. Satışa sunulan bir seri malın ayıplı olması halinde, Bakanlık, tüketiciler ve tüketici örgütleri, seri malın ayıplı olduğunun tespiti, üretiminin ve satışının durdurulması, ayıbın ortadan kaldırılması ve satış amacıyla elinde bulunduranlardan toplatılması için dava açabilirler (TKHK.m.74/1). Ayıplı mal ve hizmet hallerinde tüketicilerin satıcıya karş1 başvurabilecekleri yollar ile seçimlik hakları, sadece seri mallarla sınırlı olmayıp, tüm mallar açısından TKHK.m.8 vd. hükümlerinde düzenlenmiştir ${ }^{65}$. Tüketici örgütleri ile Bakanlığa 74. madde çerçevesinde tanınan dava hakkı ise seri mallar için tanınmıştır. Bir başka deyişle dava açabilmek için ayıplı malların satışa seri olarak sunulması gerekir. Satışa sunulan mallardaki ayıp maddi, hukuki ya da ekonomik ayıp olabilir. Üzerinde seri numarası olsun ya da olmasın aynı çeşit ve tipte çok sayıda üretilerek piyasaya sunulan mallar seri mallar olarak kabul edilir ${ }^{66}$. Așırı 1sınarak patlama tehlikesi yaratan belli seri ve modeldeki diz üstü bilgisayarlar, cilde enjekte edildiğinde alerjik reaksiyonlar oluşturan estetik ürünleri, organ hasarına neden olan zayıflama çayları, hammaddesinde kanserojen ya da sağlığa zararlı diğer maddeler bulunan oyuncaklar, ilaçlar vb. örnek olarak verilebilir. Mahkemenin satışa sunulan malın ayıplı olduğunu tespit etmesi halinde, mahkeme ayıbın niteliğine göre malın satışını geçici olarak durdurma veya ayıbı giderme kararları verebilir. Üretici veya ithalatçı, mahkeme kararının tebliği tarihinden itibaren en geç üç ay içerisinde malın ayıbını kaldırmakla yükümlü olup, malın ayıbının ortadan kalkmasının imkânsız olması halinde mal, üretici veya ithalatçı tarafından toplatılır veya toplattırılır. Toplatılan mallar ise taşıdıkları risklere göre kısmen veya tamamen imha edilir veya ettirilir. İmha edilen malla ilgili tüketicinin dava ve tazminat hakları saklıdır (TKHK.m.74/2). Maddenin son fikrasında ise, satışa sunulan bir seri malın, tüketicinin güvenliğini tehlikeye sokan bir ayıp taşıması durumunda Ürünlere İlişkin Teknik Mevzuatın Hazırlanması ve Uygulanmasına Dair Kanun hükümlerinin saklı olduğu ifade edilmiştir ${ }^{67}$. Görüldüğü üzere bu madde kapsamındaki davalar, toplumun birçok kesimini ilgilendiren, tüketicilerin ortak menfaatlerinin korunmasını amaçlayan davalardır. Kanun koyucu tarafindan madde kapsamındaki davaların dava şartı arabuluculuk kapsamı dışında bırakılması, uzmanlık isteyen bu tip uyuşmazlıkların tüketici mahkemelerinde çözüme bağlanması oldukça kanaatimizce de oldukça yerindedir.

65 Tüketiciler bireysel olarak TKHK.m.8 ve devamı hükümlerine dayanarak seçimlik olarak tanınan, ayıplı mal ve hizmetlere ilişkin olarak, malın bedelinden indirim, ayıpsız olanı ile değiştirilmesi, ödenen bedelin alıcıya iadesi ve satıya malın geri verilmesi, tüketicinin ayıptan doğan zararlarının tazmini şeklindeki haklarını kullanabilirler.

66 Zevkliler/Özel, s.502: “...üretim-imalat seri numarası yazılı olarak satışa sunulan otomobil ve elektronik cihazların..., alaşımında veya hammaddesinde zehirli ve zararlı madde bulunan tencere, tava vb. mutfak araçlarının satışa sunulması, cilde zararlı olduğu belirlenen maddeden dokunmuş iç çamaşırının piyasaya sunulması, yalıtımı iyi yapılmamış ve elektrik çarpması tehlikesi taşıyan seri dışı çok sayıda aracın piyasaya sürülmesi, sağlığı tehdit eden maddeler içeren temizlik malzemelerinin piyasaya sunulması...”.

${ }^{67} 4703$ sayılı Ürünlere İlişskin Teknik Mevzuatın Hazırlanması ve Uygulanmasına Dair Kanun'un 5. ve 11. maddesi ile tüketicinin güvenliğini tehlikeye atan ürünlere ilişkin daha etkin korunması için ayrıntılı düzenlemeler getirilmiştir. 


\section{e. Tüketici İşlemi Mahiyetinde Olan ve Taşınmazın Aynından Doğan Uyuşmazlıklar}

Ayni haklar sahibine eşya üzerinde doğrudan hakimiyet ve yararlanma yetkisi sağlayan, herkese karşı ileri sürülebilen, herkesin kendisine riayetle yükümlü olduğu mutlak haklardandır. Ayni hak sahibi, hakkını kim ihlal ederse, ondan bu hakkına uymasını isteyebilir, mesela üçüncü kişilerin ihlallerine karşı istihkak ve el atmanın önlenmesi davalarıyla koruma sağlayabilir ${ }^{68}$.

TKHK.m.73/A-d gereğince, tüketici işlemi mahiyetinde olan ve taşınmaz eşyaların aynından doğan, bir başka deyişle taşınmaz eşya üzerinde kurulan, sahibine doğrudan hakimiyet sağlayıp herkese karşı ileri sürülebilen haklarla ilgili uyuşmazlıklardan kaynaklanan davalar, dava şartı arabuluculuk kapsamı dışında bırakılmıştır. Taşınmazın aynından doğan davalar doğrudan doğruya taşınmaz üzerindeki bir ayni hakka, mesela mülkiyet hakkına dayanan istihkak davası olabileceği gibi, şahsi bir talep hakkı doğuran sözleşmeye dayanarak taşınmaz üzerinde bir ayni hak değişikliği veya ayni hak sahipliğinde bir değişiklik ortaya çıkaran davalar da taşınmazın aynına ilişkin dava olarak kabul edilmektedir ${ }^{69}$. Ancak taşınmazla ilgili olsa dahi taşınmaz üzerinde ayni hak değişikliğine dayanmayan şahsi hakka ilişkin olan davalar, mesela tazminat davaları taşınmazın aynına ilişkin olmadığı için dava şartı arabuluculuk uygulamasına dahil olacaktır. Tüketici uyuşmazlıkları açısından değerlendirildiğinde, tüketici işlemi mahiyetinde olan konut ve tatil amaçlı taşınmazların aynından kaynaklanan uyuşmazlıklarda mesela devre mülk sözleşmeleri (TKHK.m.50), ön ödemeli konut sözleşmeleri (TKHK.m.40), konut finansman sözleşmelerinden (TKHK.m.32) ${ }^{70}$ kaynaklanan uyuşmazlıklarda, kanun koyucu, davanın arabuluculuk yöntemi ile değil mahkemece çözümlenmesini hükme bağlamıştır. Bir başka deyişle dava açmadan önce arabulucuya başvurmak zorunlu değildir, ancak ihtiyari olarak arabulucuya başvurma imkânı saklıdır ${ }^{71}$.

\section{Tüketici Uyuşmazlıklarında Arabuluculuğa İlişkin Tüketici Lehine Getirilen Düzenlemeler}

TKHK.m.73/A hükmü, zayıf konumdaki tüketiciyi korumak amacıyla, diğer dava şartı arabuluculuk düzenlemelerinden farklı olarak, dava şartı arabuluculuk sürecinde tüketiciyi koruyucu ek önlemler getirmiştir.

68 Oğuzman, Kemal /Seliçi, Özer /Oktay Özdemir, Saibe. Eşya Hukuku, İstanbul 2020, s.14 vd., Ünal, Mehmet /Başpınar, Veysel. Şekli Eşya Hukuku, Ankara, 2012, s.64 vd. TMK. m.683/1 hükmüne göre, "Bir şeye malik olan kimse, hukuk düzeninin sinırları içinde, o şey üzerinde dilediği gibi kullanma, yararlanma ve tasarrufta bulunma yetkisine sahiptir". TMK m. 683/2 hükmüne göre, "Malik, malını haksız olarak elinde bulunduran kimseye karşı istihkak davası açabileceği gibi, her türlü haksız el atmanın önlenmesini de dava edebilir”.

696100 sayılı Hukuk Muhakemeleri Kanunu md.12 gerekçesinde konu ayrıntılı olarak açıklanmıştır.

70 TKHK.m.40; “Ön ödemeli konut satış sözleşmesi, tüketicinin konut amaçlı bir taşınmazın satış bedelini önceden peşin veya taksitle ödemeyi, satıcının da bedelin tamamen veya kısmen ödenmesinden sonra taşınmazı tüketiciye devir veya teslim etmeyi üstlendiği sözleşmedir"; TKHK.m.50; "Devre tatil sözleşmesi, bir yıldan uzun süre için kurulan ve tüketiciye bu süre zarfinda birden fazla dönem için bir veya daha fazla sayıda gecelik konaklama imkânı veren sözleşmelerdir”; TKHK.m.32; “ (1) Konut finansmanı sözleşmesi, konut edinmeleri amacıyla; tüketicilere kredi kullandırılması, konutların finansal kiralama yoluyla tüketicilere kiralanması, sahip oldukları konutların teminatı altında tüketicilere kredi kullandırılması ve bu kredilerin yeniden finansmanı amacıyla kredi kullandırılmasına yönelik sözleşmedir. (2) Konut finansmanı sözleşmesi yazılı olarak kurulmadıkça geçerli olmaz. Geçerli bir sözleşme yapmamış olan konut finansmanı kuruluşu, sonradan sözleşmenin geçersizliğini tüketicinin aleyhine olacak şekilde ileri süremez", şeklinde düzenlenmiştir.

71 Akipek/Yıldırım/Ermenek/Kutlay, s.124, Koçyiğit/Yeşilkaya, s.535. 
$\mathrm{Bu}$ hükümlerden ilki, tüketicinin arabuluculuk ilk toplantısına katılmaması halinde genel olarak arabuluculuk hükümlerinden ayrık bir hukuki sonuca tabi olmasıdır. 6325 sayılı Hukuk Uyuşmazlıklarında Arabuluculuk Kanununun 18/A-11 maddesine göre; "Taraflardan birinin geçerli bir mazeret göstermeksizin ilk toplantıya katılmaması sebebiyle arabuluculuk faaliyetinin sona ermesi durumunda toplantiya kattlmayan taraf, son tutanakta belirtilir ve bu taraf davada kısmen veya tamamen haklı çıksa bile yargılama giderinin tamamından sorumlu tutulur. Ayrıca bu taraf lehine vekâlet ücretine hükmedilmez. Her iki tarafin da ilk toplantrya katılmaması sebebiyle sona eren arabuluculuk faaliyeti üzerine açılacak davalarda tarafların yaptıkları yargılama giderleri kendi üzerlerinde bırakılır". Madde hükmünden de anlaşıldığı üzere, taraflardan birinin arabuluculuk ilk toplantısına mazeretsiz katılmaması nedeniyle arabuluculuk faaliyetinin sona ermesi durumunda, toplantıya katılmayan taraf için bir müeyyide getirilmiş, bu durum son tutanakta belirtilerek, taraf davada kısmen veya tamamen haklı çıksa bile yargılama giderlerinden sorumlu tutulmuş, hatta bu taraf lehine vekalet ücretine dahi hükmedilmeyeceği, yine her iki tarafin da katılmaması halinde ise tarafların yaptıkları yargılama giderleri kendi üzerlerinde bırakılacağı belirtilmiştir. Kanaatimizce bu düzenleme ile tarafların arabuluculuk sürecine fiilen katılımının sağlanması amaçlanmıştır. Tüketicinin korunması amacıyla getirilen TKHK.m.73/A-2 hükmünde ise; HUAK.m.18/A-11 hükmünün tüketici aleyhine uygulanmayacağı düzenlenmiş olup, arabuluculuk ilk toplantısına katılmayan tüketici aleyhine yargilama gideri ve arabuluculuk ücretine hükmedilemeyeceği, davadaki haklılık durumuna göre tüketici lehine vekalet ücretine de hükmedileceği açıkça belirtmiştir. Bu hüküm, her ne kadar tüketicin korunması amacıyla düzenlense de kanaatimizce alternatif yöntem olarak arabuluculuğun toplumda yerleşmesi yönünden çelişkili sonuçlar doğurabilir. Tüketicinin toplantıya katılmamasının müeyyidesi olmayınca katılımın dolayısıyla arabuluculuktan beklenen fiili faydanın sağlanması ihtimali zayıflayacaktır.

Tüketici lehine getirilen diğer önemli düzenlemeler, arabuluculuk ücreti ile yargılama giderleri hakkındadır. TKHK.m.73/A-3,4 hükümleri ile arabuluculuk süreci boyunca tüketicinin korunarak zarar görmemesi amaçlanmaktadır.

Arabuluculuk ücreti ile ilgili genel düzenleme Hukuk Uyuşmazlıklarında Arabuluculuk Kanunu'nda düzenlenmiştir. Tarafların başvurdukları arabuluculuk yöntemi ihtiyari arabuluculuk ise, arabuluculuk süreci anlaşma ile bitsin ya da bitmesin, aksine anlaşma yoksa arabuluculuk ücreti her halde taraflarca eşit olarak karşılanır (HUAK.m.7/2) ${ }^{72}$. Dava şartı arabuluculukta ise arabuluculuk ücreti, tarafların arabuluculuk faaliyeti sonucunda anlaşmaları halinde, aksi kararlaştırılmadıkça taraflarca eşit şekilde karşılanmakta (HUAK.m.18/A-12), tarafların anlaşamamaları halinde ise, iki saatlik ücret tutarı Arabuluculuk Asgari Ücret Tarifesine göre Bakanlık bütçesinden karşılanmakta, iki saatten fazla süren görüşmelerde, iki saati aşan kısma ilişkin ücret taraflarca eşit olarak tarifenin birinci kısmına göre karşılanmakta ve yargılama giderlerinden sayılmaktadır (HUAK.m.18/A-13) ${ }^{73}$. Bu genel hükümler dışında Hukuk

72 HUAK.m.7/2; “Aksi kararlaştırılmadıkça, arabulucunun ücreti, faaliyetin sona erdiği tarihte bulunan Arabuluculuk Asgari Ücret Tarifesine göre belirlenir ve ücret ile masraf taraflarca eşit olarak karşılanır".

73 HUAK.m.18/A-12; "Tarafların arabuluculuk faaliyeti sonunda anlaşmaları halinde, arabuluculuk ücreti, Arabuluculuk Asgari Ücret Tarifesinin eki Arabuluculuk Ücret Tarifesinin İkinci Kısmına göre aksi kararlaştırılmadıkça taraflarca eşit şekilde karşılanır. Bu durumda ücret, Tarifenin Birinci Kısmında belirlenen iki saatlik ücret tutarından az olamaz”. HUAK.m.18/A-13; “Arabuluculuk faaliyeti sonunda taraflara ulaşılamaması, 
Uyuşmazlıklarında Arabuluculuk Kanunu'nda, özel kanunlarda dava şartı arabuluculuğa ilişkin kabul edilen özel hükümlerin saklı olduğu belirtilmiştir ${ }^{74}$. İlgili kanunda hüküm bulunan hallerde özel kanun, aksi halde HUAK.m.18 hükmünün uygulanacağı açıktır. Tüketicinin Korunması Hakkındaki Kanun da özel kanun olması nedeniyle ücrete ilişkin hükümlerde, tüketicinin hakları gözetilerek hazırlanan bu kanun hükümleri uygulanacaktır.

Tüketici uyuşmazlıklarında tüketici arabuluculuk ücreti ödemeyeceği, tüketicinin ödemesi gereken ücretin Adalet Bakanlığı bütçesinden karşılanacağı TKHK.m.73/A-3 ile açıkça belirtilmiştir. Buna göre, "Arabuluculuk faaliyeti sonunda taraflara ulaşılamaması, taraflar katılmadığı için görüşme yapılamaması veya tarafların anlaşmaları ya da anlaşamamaları hâlinde tüketicinin ödemesi gereken arabuluculuk ücreti, Adalet Bakanlığı bütçesinden karşılanır. Ancak belirtilen hâllerde arabuluculuk ücreti, Arabuluculuk Asgari Ücret Tarifesinin eki Arabuluculuk Ücret Tarifesinin Birinci Kısmına göre iki saatlik ücret tutarını geçemez”. Kanaatimizce zayıf tarafın en iyi korunma yönteminin yargısal yöntem olduğu kuşkusuzdur, ancak bu hükümdeki gibi alternatif yöntemlerle getirilen özel düzenlemelerle de koruma işlevi sağlanabilir ${ }^{75}$. Madde içeriğine baktığımızda, kanun koyucunun, arabuluculuk faaliyeti sürecindeki her türlü alternatifi ayrı ayrı belirterek tüketicinin ücret ödemeyeceğini özellikle vurgulamış olduğunu görüyoruz. Dava şartı arabuluculuk kapsamındaki bir tüketici uyuşmazlığında, arabuluculuk faaliyeti sonunda taraflara ulaşılamaması, katılım sağlanmadığı için görüşme yapılamaması, tarafların anlaşması ya da anlaşamamaları hallerinin hiçbirinde tüketici ücret ödemeyecektir. Tüketicinin ödemesi gereken ücret Adalet Bakanlığı bütçesinden karşılanacaktır. Ancak ücretin miktarı sınırlandırılmıştır. Uyuşmazlık konusu meblağ ne olursa olsun, diğer dava şartı arabuluculuk hallerinden farklı olarak bu hükümle, Arabuluculuk Asgari Ücret Tarifesi çerçevesinde iki saatlik ücreti geçemeyeceği belirtilmiştir ${ }^{76}$. Bu madde kapsamında akla gelen sorulardan birisi de arabuluculuk sürecinin anlaşma ile sona ermesi halinde tarafların bu hükmün aksini kararlaştırabilip kararlaştıramayacakları hususudur. Arabuluculuk ücretinin satıc1/sağlayıcı tarafından ödeneceği yönündeki anlaşmalarda satıc1/sağlayıcı ücreti öder. Ancak tüketicinin ücret ödeyeceğine dair anlaşmaların geçerli olmayacağı kanaatindeyiz. Zira bu hükmün getiriliş amacı (ratio legis) tüketiciyi korumak, onu külfete maruz bırakmamaktır. Aksi takdirde tüketici içinde bulunduğu uyuşmazlık açısından zayıf taraf olarak anlaşma yapmaya mecbur bırakılabilir.

Tüketicinin ücret ödemeyeceğine ilişkin olarak getirilen bu hüküm arabuluculuk faaliyeti sonucunda açılan davanın tüketici lehine sonuçlanması halinde, onun lehine yargılama giderine

taraflar katılmadı̆̆ı için görüşme yapılamaması veya iki saatten az süren görüşmeler sonunda tarafların anlaşamamaları hallerinde, iki saatlik ücret tutarı Tarifenin Birinci Kısmına göre Adalet Bakanlığı bütçesinden ödenir. İki saatten fazla suren görüşmeler sonunda tarafların anlaşamamaları halinde ise iki saati aşan kısma ilişkin ücret aksi kararlaştırılmadıkça taraflarca eşit şekilde uyuşmazlığın konusu dikkate alınarak Tarifenin Birinci Kısmına göre karşılanır. Adalet Bakanlığı bütçesinden ödenen ve taraflarca karşılanan arabuluculuk ücreti, yargılama giderlerinden sayılır."

74 HUAK.m.18/A-19; "İlgili kanunlarda dava şartı olarak arabuluculuğa ilişkin kabul edilen özel hükümler saklıdır.”.

75 Arabuluculuk sürecinde zayıf tarafın korunması hakkında ayrıntılı bilgi için bkz., Ermenek, s.45 vd.

762021 yılı için en fazla 340 TL olan bu miktar, uygulamada arabulucular tarafindan özellikle yüksek meblağlı uyuşmazlıklarda ücret kaybına yol açtığı için eleştirilmektedir. Ancak tüketici hukukunun temeli tüketicinin korunması esasına dayanır. Tüketicinin menfaati üstündür, bu nedenle kanaatimizce de tüketiciye külfet yüklenmemiş olması isabetlidir. 
hükmedilmesine engel teşkil etmez ${ }^{77}$. Nitekim TKHK.m.73/A-4 hükmü ile de bu husus belirtilmiştir; "Arabuluculuk faaliyeti sonunda açılan davanın tüketici lehine sonuçlanması hâlinde arabuluculuk ücreti, 6183 sayll Kanun hükümlerine göre davalıdan tahsil olunarak bütçeye gelir kaydedilir.”. Kanun hükmü tüketici lehine sonuçlanan davanın yargılama giderlerinin davalıdan tahsil edileceği ifade edilmişse de tüketicinin davalı olması durumunda da davacıdan tahsil edileceği şüphesizdir. Zira tüketici işlemi niteliğindeki bir uyuşmazlıkta satıc1/sağlayıcı davacı, tüketici de davalı olabilir. Kanun hükmünün bu bağlamda tüketici lehine sonuçlanan davada arabuluculuk ücretinin diğer taraftan tahsil olunarak bütçeye gelir kaydedilir şeklinde anlaşılması daha isabetli olacaktır.

\section{SONUÇ}

Toplumsal düzenin sağlanması için en önemli unsurlardan birisi uyuşmazlıkların en kısa sürede ve menfaatler dengesine en uygun biçimde çözümlenmesidir. Uyuşmazlık çözümlerinde temel yöntem yarg1 yetkisinin mahkemelere ait olduğu adli sistemdir. Ancak sosyal, ekonomik, teknolojik gelişmeler ihtiyaçların ve uyuşmazlıkların çeşitlenmesine, dolayısıyla mahkemelerin iş yükünün artmasına, yargı sürecinin uzamasına ve adaletin gecikmesine sebep olmuştur. Bu süreç içerisinde hukuk sistemleri alternatif çözüm yöntemlerini benimsemiş ve uygulamaya başlamıştır. Arabuluculuk yöntemi ise en çok uygulanan ve tercih edilen yöntem olarak karşımıza çıkmaktadır. Ülkemizde öncelikle ihtiyari olarak uygulanmaya başlayan arabuluculuk yöntemi, toplumsal farkındalığın hızlandırılması amacıyla önce iş hukuku, daha sonra ticaret hukuku ve son olarak tüketici hukukunda dava şartı haline gelmiştir.

Tüketici hukuku dünyada ve ülkemizde çok hızlı gelişen ve değişen, uyuşmazlıkların gittikçe farklılaşıp fazlalaştığı hukuk dallarından birisidir. Sanayileşme ve küreselleşme ile ürün çeşitliliğinin artması, güçlü taraf karşısında tüketicilerin korunması ve bu konuda yeni hukuki düzenlemeler yapılması sonucunu doğurmuştur. Bu düzenlemelerle zayıf konumdaki tüketicilerin sağlık ve güvenliği ile ekonomik menfaatlerinin gözetilmesi amaçlanmıştır. 6502 sayılı Tüketicinin Korunması Hakkında Kanun da bu amaçlar doğrultusunda hazırlanmıştır. Ancak uygulama alanının (tüketici işlemi ve tüketici mahkemelerinin görev alanı) oldukça geniş tutulması tüketici mahkemelerinin iş yükü oldukça artmıştır. Zira bir uyuşmazlığın tüketici işlemi olması veya tüketiciye yönelik uygulamalardan doğması halinde tüketici mahkemeleri görevlidir. Tüketici mahkemelerinin artan iş yükü tüketici uyuşmazlıklarının daha uzun bir süreçte ve daha masraflı olarak çözümlenmesine neden olmaktadır. Tüketicinin uyuşmazlığın zayıf tarafı olması dikkate alındığında karşı karşıya kaldığı uyuşmazlık ne kadar hızlı, tasarruflu, pratik olarak çözümlenirse, o kadar etkili korunma sağlanabilir. Tüketici uyuşmazlıkları tarafların üzerinde serbestçe tasarruf edebilecekleri uyuşmazlıklardandır. Bu çerçevede arabuluculuğun tüketici uyuşmazlıkları açısından yararlı olacağı haklı düşüncesi ile, 7251 sayılı Hukuk Muhakemeleri Kanunu ve Bazı Kanunlarda Değişiklik Yapılması Hakkındaki Kanun ile 6502 sayılı Tüketicinin Korunması Hakkında Kanun'a "Dava şartı arabuluculuk” başlığı ile eklenen 73/A maddesi ile tüketici uyuşmazlıklarında da dava açılmadan önce arabulucuya başvurulmuş olması zorunlu hale getirilmiştir. Çalışmamızda ayrıntılı olarak belirtildiği üzere, tüketiciyi koruma ilkesi de gözetilerek hazırlanan madde hükmünde, arabuluculuğa başvuru zorunluluğu kapsamındaki

77 Akipek/Yıldırım/Ermenek /Kutlay, s.125, Koçyiğit /Yeşilkaya, s.537. 
uyuşmazlıklar ve istisnaları ile arabuluculuk ücretinin ödenme usulüne yer verilmiş, madde kapsamındaki haller dışında tüketici uyuşmazlıklarında arabuluculuğa başvuru zorunluluğu HUAK.m.18/A hükmüne tabi tutulmuştur.

Kanaatimizce, hukuk sistemimiz içinde tüketici uyuşmazlıklarında dava şartı arabuluculuk yönteminin benimsenmiş olması, toplumda bu konuda farkındalık yaratacaktır. Tüm dünyada olduğu gibi ülkemizde de birçok olumsuz sonuçlara neden olan pandemi süreci ve sonucunda tüketici alanındaki uyuşmazlıkların yoğun artışı ile arabuluculuk yöntemi gözönünde olacaktır. Arabuluculuk tarafların serbest ve açık bir müzakere süreci içerisinde dış baskıya maruz kalmadan görüşmeler yapabildiği, bu sürecin olumlu sonuçlanmaması ihtimalinde yine yargıya başvurulabilen menfaat temelli bir yöntemdir. Taraflar uyuşmazlığı daha esnek olarak kendi istek ve ihtiyaçlarını ön plana alarak uzman arabulucunun desteği ile çözüme kavuşturabilirler. Tüketicinin bilgisizlik, tecrübesizlik, ekonomik açıdan güçsüzlük gibi nedenlerden dolayı zayıf taraf olarak yer aldığı tüketici uyuşmazlıklarında, arabuluculuğun başarılı olabilmesi, uyuşmazlık konusu hakkında uzman, tarafsız ve bağımsız arabulucuların uyuşmazlık konusunu inceleyip değerlendirerek taraflara teknik ve detaylı destek sağlamasına bağlıdır. Bu desteğin sağlanabilmesi için arabulucunun özel uzmanlık ve teknik bilgi gereken tüketici hukuku alanında uzman olması gereklidir, ancak yeterli olamayacaktır. Kanaatimizce tüketiciyi koruma ilkesi temel alınmak şartıyla, arabuluculuğun değerlendirici arabuluculuğa doğru yönelmesi gerekir. Uzman arabulucu uyuşmazlığın çözümü için hukuk kurallarının çözümlerini ve sonuçlarını bilmeli, taraflara iletebilmeli ve çözüm önerilerinde bulunabilmelidir. Bu şekilde uyuşmazlık çözümü mahkemelere nazaran hem daha az masraflı hem daha hızlı aynı zamanda kaybedenin olmadığı her iki tarafın da kazandığı menfaat temelli bir çözüme kavuşturulabilir.

\section{KAYNAKÇA}

Abugalı, Gulden. Tüketici Hukukundan kaynaklanan Uyuşmazlıkların Türk ve Rus Hukukuna Göre Arabuluculukla Çözülmesi, Ankara, 2020.

Akipek Öcal, Şebnem. "6502 sayılı Tüketicinin Korunması Hakkında Kanun Kapsamında Tüketici İşlemi ve Usul Hukuku Bakımından Etkileri”, Tüketici Hukukunda Uyuşmazlık Çözümüne İlişkin Güncel Sorunlar ve Çözüm Önerileri Sempozyumu, Editör, Ertan Yardım, Seçkin Yayınları, Ankara, 2018, s.1727.

Akipek, Şebnem/Yıldırım, Abdülkerim/Ermenek, İbrahim/Kutlay, Selda. Tüketici Hukukunda Uzman Arabuluculuk, AB.Hukuk Işsleri Genel Müdürlü̆̈̈̈ Arabuluculuk Daire Başkanlı̆ğ Temel Eğitim Kitapçı̆̆l, Ankara, 2021. Ankara, 2019.

Albayrak, Âdem /Koçyiğit İlker. Sorularla Arabuluculuk Sınavına Hazırlık, Adalet Yayınevi,

Arslan, Ramazan/ Yılmaz, Ejder/Taşpınar Ayvaz, Sema/Hanağası, Emel. Medenî Usul Hukuku, 5. Bask1, Ankara, 2019.

Aslan, İ.Yılmaz. Tüketici Hukuku Dersleri, 8.Bask1, Ankara, 2021.

Atalı, Murat. "Yargılama İlkeleri Çerçevesinde Tüketici Hakem Heyetleri”, Tüketici Hukukunda Uyuşmazlık Çözümüne İlişkin Güncel Sorunlar ve Çözüm Önerileri Sempozyumu, Editör, Ertan Yardım, Seçkin Yayınları, Ankara, 2018, s.69-86.

Atalı, Murat/ Ermenek, İbrahim/ Erdoğan, Ersin. Medenî Usul Hukuku, 2. Bask1, Ankara, 2019. 
Aydoğdu, Murat. Tüketici Hukuku Dersleri, Ankara 2015.

Bercovitch, Jacob. International Mediation,, Chicago, 1991. s. $30-48$.

Bulur, Alper. "Alternatif Uyuşmazlık Çözüm Yolları ve Arabuluculuk Yöntemi”, ABD, S. 4, 2007,

Çelikoğlu, Cengiz Topel. 6325 Sayılı "HUAK'a göre Arabuluculuk Yoluna Başvurulması ve Çözüm Anlaşmasının Mahkeme ve İcra Usulleri ile İlişkisi”, Prof. Dr. Ejder Yılmaz' a Armağan, C.I, Ankara, 2014, s.699-723. 2018.

Dür, Orhan. Arabuluculuk Faaliyeti ve Arabulucuların Hak ve Yükümlülükleri, 2. Bask1, Ankara,

Ekmekçi, Ömer/Özekes, Muhammet/Atalı, Murat. Hukuk Uyuşmazlıklarında İhtiyarî ve Zorunlu Arabuluculuk, İstanbul, 2018.

Ekmekçi, Ömer/Özekes, Muhammet/ Atalı, Murat / Seven, Vural. Hukuk Uyuşmazlıklarında Arabuluculuk, 2. Bası, Ankara, 2019.

Ermenek, İbrahim. "Dava Şartının Arabulucu Tarafından Kendiliğinden Dikkate Alınması Sorunu ve Bu Kapsamda Yapılan Hataların Düzeltilmesi”, YD.2020/4, C.46, s.1017-1062.

Gümüş, Alper. "6502 Sayılı Tüketicinin Korunması Hakkında Kanuna Genel Bir Bakış”, Sektörel Bazda Tüketici Hukuku ve Uygulamaları (2014-2015), Editörler; Av. Hakan Tokbaş, Fehim Üçışı, 4. Tüketici Hukuku Kongresi, Ankara, 2015.

Güngör, Hüseyin. Arabuluculuk, Ankara, 2008.

Güngör Güneysu, Gülin. Milletlerarası Özel Hukukta Tüketicinin Korunması, Ankara,2000.

Ildır, Gülgün. Alternatif Uyuşmazlık Çözümü, Ankara, 2003 (2003).

Ildır, Gülgün. “Alternatif Uyuşmazlık Çözümü ve Hak Arama Özgürlüğü”, 75. Yaş Günü için Prof. Dr. Baki Kuru Armağanı, Ankara, 2005, s. 385-401 (2005).

İlhan, Onur. Arabuluculuk Sözleşmesi, Ankara, 2020.

Kara, İlhan. Yeni Kanuna Göre Tüketici Hukuku, Ankara, 2015.

Kekeç, Elif Kısmet. Arabuluculuk Yoluyla Uyuşmazlık Çözümünde Temel Aşamalar ve Taktikler, 3. Bask1, Ankara, 2016.

Koçyiğit,İlker/Yeşilkaya,İzzet. Ticari Davalarda, İs Uyuşmazlıklarında, Tüketici Mahkemelerinde Dava Şartı Arabuluculuk Uygulamalarl, Ankara, 2020.

Kuru, Baki/ Arslan, Ramazan/ Yılmaz, Ejder. Medenî Usul Hukuku, 25. Bask1, Ankara, 2014.

Moore, Cristopher W. Arabuluculuk Süreci, Anlaşmazlık Çözümünde Pratik Stratejiler, The Mediation Process, (Çev. Tarkan Kaçmaz, Mustafa Tercan), 4. B., Ankara, 2016.

Narbay, Şafak/Akkuş, Muhammed. "Ticari İş ve Tüketici İşlemi Kavramları Ekseninde Görevli Mahkeme Ve Dava Şartı Arabuluculuk Üzerine Düşünceler”, TAAD., Y.11, S.44, Ekim,2020, s.301-334.

Oğuzman, Kemal /Seliçi, Özer /Oktay Özdemir, Saibe. Eşya Hukuku, İstanbul, 2020. 475.

Özbay, İbrahim. “Alternatif Uyuşmazlık Çözüm Yöntemleri”, EÜHFD., C. X, S. 3-4, 2006, s. 459-

Özbek, Mustafa. Alternatif Uyuşmazlık Çözümü, C. 1, 4. B., Ankara, 2016 (2016).

Özbek, Mustafa. “Avrupa Konseyi Arabuluculuk Yönergesi Önerisi”, AÜHFD., C. 56, S. 1, 2007, s. 183-231 (2007).

Özekes, Muhammet. Tüketici Uyuşmazlıklarında Zorunlu Arabuluculuk, 1. Bası, İstanbul, 2021.

Özel, Çağlar. Tüketicinin Korunması Hukuku, Ankara, 2019. 
Özmumcu, Seda. Uzak Doğu'da Arabuluculuk Anlayışı ile Türk Hukuk Sisteminde Arabuluculuk Kurumuna Genel Bir Baklş, 3. Baskı, İstanbul, 2013.

Pekcanıtez, Hakan/ Özekes, Muhammet/ Akkan, Mine/ Korkmaz Taş, Hülya. Medenî Usul Hukuku, 15. Bask1, C. 1, İstanbul, 2017 (C.1).

Pekcanıtez, Hakan/Özekes, Muhammet/ Akkan, Mine/Korkmaz Taş, Hülya. Medenî Usul Hukuku, 15. Bask1, C. 3, İstanbul, 2017 (C.3).

Roberts, Marien. Aile Uyuşmazlıklarında Arabuluculuk Uygulama Esasları, Ankara, 4.Basımdan Çeviri, Şubat 2020.

Sabuncuoğlu, Zeyyad Ziya. Hukuk Uyuşmazlıklarında Arabuluculuk, Bursa, 2016.

Sarısözen, Serhat. "Hukuk Uyuşmazlıklarında Arabuluculuk Kanun Tasarısının Getirdikleri, İcra Edilebilirlik Belgesi ve Arabuluculuğun Avukatın Tekel Hakkına Aykırılık Oluşturup Oluşturmadığı Sorunu", EÜHFD., C.XV, 2011/1-2, s.255-271.

Sevim, Onur Utku. Avrupa Birliği Müktesebatı ve Türk Hukukunda Arabuluculuk, Ankara, 2016.

Şahin, Tuğçem/Çelik, Yasin/Ruhi, Ahmet Cemal. Hukuk Uyuşmazlıklarında Arabuluculuk Rehberi, Ankara, 2018.

Tanrıver, Süha. "Alternatif Uyuşmazlık Çözüm Yolları: Arabuluculuk Kurumuna Hukukî ve Sosyolojik Bir Bakış”, Prof. Dr. Fikret Eren'e Armağan, Ankara, 2006, s.821-842 (2006).

Tanrıver, Süha. Hukuk Uyuşmazlıkları Bağlamında Alternatif Uyuşmazlık Çözüm Yolları ve Özellikle Arabuluculuk, Makalelerim II, Ankara, 2011 (2011).

Taşpınar Ayvaz, Sema. "Tüketici Hakem Heyetlerinin Hukuki Niteliği”, Tüketici Hukukunda Uyuşmazlık Çözümüne İlişkin Güncel Sorunlar ve Çözüm Önerileri Sempozyumu, Editör, Ertan Yardım, Seçkin Yayınları, Ankara, 2018, s.43-51.

T1ktık Yazıcı, Çiğdem. Arabuluculukta Gizliliğin Korunması, İstanbul, 2013.

Tuğsavul Taşpolat, Melis. Türk Hukukunda Arabuluculuk, Ankara, 2012 (2012).

Tuğsavul Taşpolat, Melis. "Topluluk Davalarının Tüketicinin Korunması Hakkında Kanun Bakımından Değerlendirilmesi”, Tüketici Hukukunda Uyuşmazlık Çözümüne İlişkin Güncel Sorunlar ve Çözüm Önerileri Sempozyumu, Editör, Ertan Yardım, Ankara, 2018, s.101-118 (2018).

Tutumlu, Mehmet Akif. "Tüketici Uyuşmazlıkları Açısından Tüketici Kavramı ve bu Kavramın Kapsadığ1 Kişiler”, 5. Tüketici Hukuku Kongresi, Sektörel Bazda Tüketici Hukuku ve Uygulamaları 20152016, Editörler, Tokbaş,Hakan/Üçı̧sık, Fehim, Ankara, 2016, s.572-588 (2016).

Tutumlu, Mehmet Akif. "6502 Sayılı TKHK Hükümleri Işı̆̆ında Tüketici Hakem Heyetlerine İtiraz Davası", Tüketici Hukukunda Uyuşmazlık Çözümüne İlişkin Güncel Sorunlar ve Çözüm Önerileri Sетровуити, Editör, Ertan Yardım, Ankara, 2018, s.153-172 (2018).

Uyumaz, Alper. "Tüketici Hukukundan Doğan Alternatif Çözüm Yolları", SÜHFD., C.20, S.1,2012, s.103-132.

Ünal, Mehmet /Başpınar, Veysel. Şekli Eşya Hukuku, Ankara, 2012. 